\title{
PREVIDÊNCIA SOCIAL
}

\section{APRESENTAÇÃO}

O capítulo de Previdência Social da edição anterior deste periódico destacou, em sua apresentação, que, no final do ano de 2014, o governo federal editou a Medida Provisória (MP) no 664, que alterara algumas regras dos benefícios de pensão por morte e auxílio-doença. A análise então feita ressaltou que antes de sua eventual conversão em lei, a medida seria apreciada e possivelmente alterada no Congresso Nacional, principal fórum para discussão, a respeito de alteraçóes no regramento previdenciário.

Pois bem, o capítulo atual retoma a discussão aberta com o envio da MP no 664, destacando as alteraçóes originadas do processo de discussão e de apreciação da matéria no parlamento, chegando ao fim e ao cabo em sua conversão na Lei no 13.135/2015. Também apresenta a discussão a partir do envio da MP no ${ }^{\circ}$ 675, de 17 de junho de 2015, e o advento da fórmula 85/95 progressiva, que flexibiliza a incidência do fator previdenciário nas aposentadorias por tempo de contribuição do Regime Geral de Previdência Social (RGPS). O efeito conjugado dessas alteraçóes pode ter piorado a sustentabilidade fiscal da Previdência Social no Brasil.

Os últimos anos testemunharam o advento de medidas de desoneração previdenciária, bem como sua ampliação. A crise econômica observada ao longo de 2015, que resultou na queda da arrecadação previdenciária, bem como no resultado fiscal do governo central, aliada à falta de consenso sobre os eventuais efeitos benéficos de tais medidas resultaram em uma tentativa de recuo da política de desoneração. Esse movimento, que resultou na Lei no $13.161 / 2015$, também será analisado neste capítulo, assim como as implicações previdenciárias da regulamentação da Emenda Constitucional (EC) no 72 , consubstanciada na Lei Complementar (LC) no $150 / 2015$, que ampliou direitos trabalhistas e previdenciários das trabalhadoras domésticas.

Na seção de Acompanhamento da política e dos programas, é dado destaque para os grandes números do RGPS e dos Regimes Próprios de Previdência dos Servidores (RPPS). Destaca-se a evolução dos benefícios e despesas previdenciários no período recente.

O tema em destaque retoma e aprofunda algumas das discussóes colocadas na seção de Fatos relevantes, quais sejam, pensão por morte e a introdução do fator 85/95 progressivo. Argumenta-se que, no caso das pensóes por morte, o benefício 
passa a se aproximar do observado na experiência internacional; reduzem-se alguns incentivos para comportamentos que vão contra os objetivos do seguro social; e, em termos de gasto, argumenta-se que o maior impacto será no longo prazo devido ao grande estoque de benefícios atualmente existentes gerados pelas antigas regras.

Em relação ao fator 85/95 progressivo, questiona-se o provável crescimento da despesa com tal benefício no médio e longo prazo.

\section{FATOS RELEVANTES}

A seção de Fatos relevantes abordará cinco temas: i) as alterações nas regras das pensóes por morte e auxílio-doença trazidas na MP 664, de 30 de dezembro de 2014, e sua conversão na Lei no 13.135, de 17 de junho de 2015; ii) a MP no 675, de 17 de junho de 2015, com o veto à formula de cálculo 85/95 para as aposentadorias por tempo de contribuição e sua regra progressiva para a fórmula 90/100; iii) MP no 672, de 24 de março de 2014, convertida na Lei no 13.152, de 29 de julho de 2015, sobre o reajuste do salário-mínimo e a proposta vetada pela presidenta da ampliação da regra de correção do salário-mínimo para todas as aposentadorias; iv) a nova política de desoneração de folha promovida pela Lei no 13.161 , de 31 de agosto de 2015; e, por fim, $v$ ) a regulamentação na perspectiva previdenciária da EC no 72, de 2 de abril de 2013, sobre os trabalhadores domésticos por meio da Lei Complementar no 150, de 1ํ de junho de 2015.

\subsection{Alterações nas regras de pensões por morte e auxílio-doença}

Dentro do conjunto de medidas do ajuste fiscal tomadas no final de 2014, destacavam-se aquelas voltadas para reduzir a despesa do Regime Geral de Previdência Social, em especial, com pensão por morte e auxílio-doença, por meio da MP no 664/2014, posteriormente convertida na Lei no $13.135 / 2015$. A referida medida também buscou flexibilizar as possibilidades de execução da perícia médica ao eliminar a competência privativa dos médicos peritos do Instituto Nacional do Seguro Social (INSS) e abrir novas possibilidades de prestaçáo do serviço. A principal mudança proposta pela MP no ${ }^{\circ}$ 664/2014 foi uma grande reestruturação das regras de pensão por morte do RGPS, sendo que algumas medidas também foram estendidas para os servidores públicos federais.

A tramitação da MP nº 664/2014 no Congresso Nacional foi marcada por forte resistência às alteraçóes propostas, que se explicam pela ausência de uma negociação prévia do governo com as lideranças políticas e com a sociedade, de tal sorte, que a referida MP sofreu importantes modificaçóes durante sua tramitação no Legislativo. De forma mais precisa, foram apresentadas 517 emendas à MP no 664/2014. Um processo de negociação e debate da medida com a sociedade e o Congresso poderiam ter facilitado a tramitação e possibilitado menores alteraçóes em relação às que efetivamente ocorreram. De qualquer forma, embora o ajuste sancionado pela Lei no 13.135/2015 nas regras de pensão por morte tenha sido mais tênue que o proposto pela MP no 664 , representaram um avanço em relação à situação prevalecente antes da referida MP. 


\subsubsection{Tempo mínimo de contribuição para pensões}

Uma primeira alteração foi a introdução da exigência de carência ou tempo mínimo de contribuição de 24 meses, pois a concessão era feita apenas com a exigência de qualidade do segurado, permitindo que apenas uma contribuição no "teto" do RGPS gerasse um benefício vitalício de valor máximo. Portanto, o objetivo fundamental da medida era evitar esse tipo de comportamento distorcivo. Essa situação é claramente insustentável do ponto de vista fiscal, bem como injusta com segurados que contribuíram a vida toda e recebem benefícios com valores bem menores ou mesmo salário-mínimo. Como a maior parte dos benefícios de pensão por morte é decorrente de benefício anterior, mais especificamente da aposentadoria do instituidor, essa medida terá maior efeito sobre benefícios não precedidos, que não são a maioria.

Havia exceçôes à exigência de dois anos de contribuição, nos casos de óbito do instituidor decorrente de acidentes de trabalho ou doença profissional ou do trabalho, em que permaneceria apenas a exigência de qualidade do segurado.

Durante a tramitação da medida no Congresso Nacional e posterior sanção do Executivo, o prazo foi reduzido de 24 para 18 meses, bem como foi criado pagamento de quatro meses de benefício para segurados que não tivessem vertido esse número mínimo de contribuiçóes, o que na prática significa que o Brasil continua sendo um dos poucos países que não exigem carência. O pagamento de quatro meses ainda representa um estímulo a comportamentos diferentes do esperado, quando da elaboração da medida, embora tenha reduzido o "prêmio" desse referido comportamento. As exceçôes também foram alteradas de acidentes de trabalho para um conceito muito mais amplo e mais impreciso de acidente de qualquer natureza, sendo mantida a doença profissional ou do trabalho. Essa maior imprecisão pode elevar o nível de judicialização da concessão de benefícios do INSS, que já é relevante.

Na proposta de introdução de carência feita pela MP no 664, houve a extensão para os servidores públicos federais por meio da alteração da Lei no 8.112/1990. Note que a justificativa aqui nada tem que ver com comportamentos oportunistas, tendo em vista que a entrada no serviço público se dá por concurso público. De qualquer forma, o pagamento de quatro meses de benefício também foi estendido na versão final sancionada pela Lei no ${ }^{-13.135 / 2015}$ para servidores que não tivessem dezoito meses de contribuição, bem como também se aplicam às exceçóes nos casos do óbito do servidor que tenha sido decorrente de acidente de qualquer natureza ou doença profissional ou do trabalho. ${ }^{1}$

1. Cabe salientar que para o cumprimento da carência de dezoito meses de contribuição, tanto para trabalhadores vinculados ao RGPS quanto para aqueles vinculados a um regime de previdência de servidor público, será considerado o tempo de contribuição em ambos regimes, de tal sorte que aqueles que mudem de regime não serão prejudicados. 
De acordo com dados do Ministério do Trabalho e Previdência Social, considerando as pensões concedidas em 2014, apenas 10.742 benefícios de pensão por morte não precedidas tiveram tempo de contribuiçấo do instituidor inferior a dois anos, que era a proposta da MP no 664 , que correspondeu a 2,6\% do total de cerca de 410 mil pensôes por morte concedidas em 2014. Em relação ao parâmetro que foi sancionado pela Lei no $13.135 / 2015$, os dados apontam que 9.081 benefícios ( $2,2 \%$ da concessão total) tinham tempo de contribuição inferior a 18 meses. Portanto, nota-se que, a priori, o volume de benefícios afetados não é tâo grande, tratando-se mais de uma medida moralizadora. Nesse sentido, a instituição de pagamento de quatro meses para quem não atendesse os dezoito meses de contribuição, acabou por diminuir, mas não eliminar integralmente o incentivo para esses referidos comportamentos indesejados. Isso porque, considerando o teto do RGPS em 2015, seria possível que apenas uma contribuição de R 932,75 pudesse gerar um fluxo de benefícios de R $\$ 18.655$.

\subsubsection{Tempo mínimo de casamento ou união estável para pensões}

Outra importante alteração proposta pela MP no 664 foi a introdução de tempo mínimo de casamento ou união estável para o direito a pensão para os cônjuges. Os(As) viúvos(as) precisariam estar casados ou em união estável com o instituidor com antecedência de pelo menos dois anos em relação à data do óbito para ter direito à pensão. Contudo, novamente, esse ajuste também foi amenizado durante a tramitação no Congresso Nacional com o estabelecimento de pagamento de quatro meses de benefício para segurados que não cumprissem o tempo mínimo de casamento ou uniáo estável, o que acabou por manter algum estímulo a comportamentos oportunistas, embora reduza o valor passível de ser obtido. Cabe enfatizar que mesmo que o casamento não tivesse ocorrido há mais de dois anos antes do óbito do instituidor, caso o casal tivesse filhos menores de 21 anos haveria a concessão de pensão e proteção para os referidos filhos.

Também havia exceçôes a essa condicionalidade, mais especificamente para os casos de óbito do instituidor serem decorrentes de acidente posterior ao casamento ou ao início da união estável, bem como, se o cônjuge, o companheiro ou a companheira fossem considerados incapazes e insuscetíveis de reabilitação para o exercício de atividade remunerada que lhes garantisse subsistência, mediante exame médico-pericial a cargo do INSS. As exceções também foram modificadas, de tal sorte que, na sanção, ficou estabelecido como exceção o caso de óbito do instituidor decorrente de acidente de qualquer natureza ou doença profissional ou do trabalho sem condicionar que tenham ocorrido depois do casamento ou do início da uniẫo estável. Ademais, para cônjuges, companheiros ou companheiras com invalidez ou deficiência, o término do pagamento da pensão passa a ocorrer pela cessação da invalidez ou o afastamento da deficiência. Além da imprecisão do conceito de acidente de qualquer natureza, que pode gerar judicialização ao 
vincular o fim da pensão do cônjuge ao afastamento da deficiência, cria-se uma confusão de deficiência com incapacidade laboral.

O estabelecimento do tempo mínimo de dois anos de casamento ou união estável para cônjuges também foi estendida para os servidores públicos federais por meio de alteração na Lei no 8.112/1990.

2.1.3 Duração do benefício de pensão em função da idade do pensionista na data de óbito do instituidor

Com MP no 664, a pensão por morte deixara de ser um benefício de caráter vitalício independente da idade do(a) viúvo(a), que, por sua vez, guarda relação com sua capacidade laboral.

A experiência internacional normalmente vincula à duração da pensão com a idade do viúvo(a), sua (in)capacidade laboral ou a existência ou não de filhos. No Brasil, antes da MP no 664, havia a garantia de pensão vitalícia, mesmo se o cônjuge fosse uma pessoa jovem, com plena capacidade laboral, com excelente nível de renda e sem filhos. A presunção de dependência econômica para os cônjuges foi mantida. Na proposta estabelecida pela MP no 664 , a duração passaria a ser determinada pela expectativa de sobrevida do(a) viúvo(a), de forma que quanto maior a expectativa (menor idade) menor seria a duração do benefício, seguindo a lógica de que cônjuges jovens teriam capacidade laboral para gerar renda para a família do instituidor.

A MP n 664 estabelecia que viúvos(as) com expectativa de sobrevida igual ou menor a 35 anos teriam direito à pensão vitalícia, enquanto aqueles com expectativa acima desse patamar teriam duração variando de 3 a 15 anos. A utilização da tabela do Instituto Brasileiro de Geografia e Estatística (IBGE) vigente estabelecia na prática que apenas teriam direito ao benefício vitalício cônjuges com 44 anos de idade ou mais. Utilizando a mesma tabela do IBGE, vigente na época da MP, para viúvos(as) com menos de 44 anos de idade, a duração seria (ver tabela 1): i) 15 anos, para aqueles com idade entre 39 e 43 anos; ii) 12 anos, para aqueles com idade entre 33 e 38 anos; iii) 9 anos, para idades entre 28 e 32 anos; iv) 6 anos, para idades entre 22 e 27 anos; $v) 3$ anos, para aqueles com idade até 21 anos. Como o critério era a expectativa de sobrevida calculada pelo IBGE, haveria atualização desses limites de idade todo ano, com a publicação de nova tabela, de forma similar ao que é feito para o fator previdenciário. Cabe destacar que a duração, não necessariamente vitalícia, refere-se ao cônjuge ou companheiro(a), pois para os filhos ficava mantida a regra geral de pagamento do benefício até completarem a idade de 21 anos.

Novamente, a medida foi alterada durante a tramitação no Congresso Nacional e posterior sanção pelo Poder Executivo. Em primeiro lugar, embora tenha sido mantida a duração variável, o critério deixou de ser a expectativa de sobrevida e 
foi estabelecida uma faixa de idade que deverá ser atualizada a cada três anos de acordo com o incremento da expectativa de vida ao nascer ou quando esse indicador tiver um incremento de pelo menos um ano. De forma similar ao estabelecido pela MP no 664, o benefício vitalício continua a ser para a idade de 44 anos ou mais, mas não há vinculação com a expectativa de sobrevida e, portanto, não há alteração anual de acordo com a publicação de nova tabela do IBGE. Para pessoas com idade inferior a 44 anos, foi estabelecida a seguinte duração: i) 20 anos, entre $41 \mathrm{e}$ 43 anos de idade; ii) 15 anos, entre 30 e 40 anos de idade; iii) 10 anos, entre 27 e 29 anos de idade; iv) 6 anos, entre 21 e 26 anos de idade; v) 3 anos, com menos de 21 anos de idade. Essa medida também foi estendida aos servidores públicos federais.

Cabe reforçar que essas duraçôes estabelecidas pela sanção da Lei no 13.135/2015 e mostradas na tabela 1 não se aplicam: $i$ ) aos cônjuges com invalidez ou deficiência que, como já colocado anteriormente, têm o fim do pagamento vinculado à cessação da invalidez ou pelo afastamento da deficiência; ii) para aqueles segurados que não tivessem dezoitos meses de contribuição ou dois anos de casamento e não se enquadrassem nas exceçôes, que teriam direito a quatro meses de benefício.

TABELA 1

Duração da pensão por morte de cônjuge na MP no 664 e na Lei no 13.135/2015

\begin{tabular}{|c|c|c|c|c|}
\hline $\begin{array}{l}\text { Duração do } \\
\text { benefício na } \\
\text { MP no 664/2014 } \\
\text { em anos }\end{array}$ & $\begin{array}{l}\text { Expectativa de sobrevida } \\
(E(x)) \text { do cônjuge na data } \\
\text { de óbito do instituidor } \\
\text { MP no } 664 / 2014 \text { em anos }\end{array}$ & $\begin{array}{l}\text { Idade do cônjuge na data de } \\
\text { óbito do instituidor usando } \\
\text { tabela do IBGE vigente no } \\
\text { período da MP em anos }\end{array}$ & $\begin{array}{c}\text { Duração do } \\
\text { benefício } \\
\text { da Lei no- } \\
13.135 / 2015\end{array}$ & $\begin{array}{c}\text { Idade do cônjuge } \\
\text { na data de óbito do } \\
\text { instituidor em anos na } \\
\text { Lei no } 13.135 / 2015^{2}\end{array}$ \\
\hline 3 & $55<E(x)$ & Até 21 & 3 & Até 20 \\
\hline 6 & $50<E(x) \leq 55$ & 22 a 27 & 6 & 21 a 26 \\
\hline 9 & $45<E(x) \leq 50$ & 28 a 32 & 10 & 27 a 29 \\
\hline 12 & $40<E(x) \leq 45$ & 33 a 38 & 15 & 30 a 40 \\
\hline 15 & $35<E(x) \leq 40$ & 39 a 43 & 20 & 41 a 43 \\
\hline Vitalícia & $E(x) \leq 35$ & 44 ou mais & Vitalíía & 44 ou mais \\
\hline
\end{tabular}

Elaboração dos autores, com base na Medida Provisória no 664/2014 e na Lei no 13.135/2015.

Notas: ${ }^{1}$ Atualização das idades com periodicidade anual em função da nova tabela de expectativa de sobrevida do IBGE;

${ }^{2}$ Atualização das idades com periodicidade de no mínimo três em três anos pelo incremento da expectativa de vida ao nascer ou quando esse indicador tiver um incremento de pelo menos um ano.

\subsubsection{Crime doloso e pensão por morte}

Um importante aperfeiçoamento da legislação previdenciária no país foi a previsão legal de perda de direito a pensão por morte para dependente condenado que cometesse crime doloso que resultasse na morte do instituidor. Essa restrição não existia na legislação previdenciária e havia a possibilidade de suspensão do pagamento por parte do INSS por açáo administrativa, mas sem base legal. Mesmo essa mudança, cujo conteúdo certamente não é polêmico, também foi modificada no Congresso Nacional, com alteração para transitado em julgado e não mais condenado. $\mathrm{Na}$ prática, isso pode implicar o pagamento por longo período de tempo até que o benefício possa ser efetivamente cessado, sendo que 
esses pagamentos podem ser de difícil recuperação. Embora tal mudança possa ser considerada defensável do ponto de vista do amplo direito de defesa, havia a possibilidade de que um condenado em primeira instância pudesse receber o benefício de forma retroativa caso posteriormente fosse comprovada ou declarada judicialmente sua inocência. Fica a dúvida de qual será o procedimento na prática do INSS, que vinha suspendendo pagamentos de pensão nesses casos mesmo sem a previsão legal, ou seja, se haverá a suspensão já com a condenação ou efetivamente apenas quando transitado em julgado. Essa medida também foi estendida aos servidores públicos federais, por meio de alteração da Lei no 8.112/1990.

\subsubsection{Perda da pensão em caso de simulação de casamento}

A Lei n⿳⺈ $13.135 / 2015$ foi sancionada com a introdução de um dispositivo que determina que

perde o direito à pensão por morte o cônjuge, o companheiro ou a companheira se comprovada, a qualquer tempo, simulação ou fraude no casamento ou na uniâo estável, ou a formalizaçáo desses com o fim exclusivo de constituir benefício previdenciário, apuradas em processo judicial no qual será assegurado o direito ao contraditório e à ampla defesa.

Embora a introdução desse dispositivo seja positiva e não gere nenhum prejuízo, na prática é difícil prever o impacto efetivo da medida, tendo em vista que pode haver dificuldade de comprovação da fraude.

\subsubsection{Fórmula de cálculo da pensão por morte}

Além de alterações nos critérios de elegibilidade e da duração, a MP no 664 também propôs mudanças na fórmula de cálculo do valor do benefício. Antes da referida MP, o valor da pensão por morte era dado por $100 \%$ do valor da aposentadoria que o instituidor recebia ou que teria direito caso estivesse aposentado por invalidez. No último caso, essa regra implica $100 \%$ do salário de benefício, ou seja, da média dos 80\% maiores salários de contribuição desde julho de 1994. Internacionalmente, é tradicional que a taxa de reposição da pensão por morte seja inferior a $100 \%$, em função da redução do tamanho da família. Ademais, antes da MP no 664, havia a reversão de cotas, ou seja, no caso de cessação da cota de um dependente, o valor dessa cota era revertido para os dependentes remanescentes. A título de exemplo, quando um filho atingia a idade de 21 anos, o valor da sua cota era revertido para as pessoas que ainda mantêm a condiçấo de dependente como, por exemplo, viúvo(a) e demais filhos menores de 21 anos.

A MP no 664 propôs que o valor da pensão por morte fosse de $50 \%$, de cota familiar, mais $10 \%$ por dependente da aposentadoria que o instituidor recebia ou teria direito a receber caso estivesse aposentado por invalidez e, portanto, o valor da pensão passaria a variar de acordo com o tamanho da família. Também havia a proposta do fim de reversão das cotas. 
Novamente, durante a tramitação no Poder Legislativo, houve alteração das proposições encaminhadas pelo Executivo e, nesse caso, houve rejeição integral da alteração na fórmula de cálculo do valor dos benefícios e no fim da reversão das cotas, voltando à situação anterior da MP. Portanto, retornou a integralidade no valor do benefício e a manutenção da reversão de cotas.

De modo geral, pode-se afirmar que a minirreforma, concretizada em 2014, por meio da Medida Provisória n ${ }^{\circ}$ 664, de 30 de dezembro de 2014 (convertida na Lei no ${ }^{-13.135 / 2015}$, alterando a Lei no 8.213/1991), efetivamente reduziu a distância entre a normativa brasileira e a realidade internacional no tocante a esse importante benefício previdenciário, mas ainda permaneceram diferenças significativas. Ademais, as modificaçóes realizadas no Congresso diminuíram de forma muito significativa o impacto fiscal das mudanças, bem como ainda mantiveram a possibilidade ou incentivo para comportamentos distorcidos. De qualquer forma, há que se reconhecer que as novas regras sancionadas pela Lei no 13.135/2015 representaram avanço em relação à situação prevalecente antes da referida MP no que se refere às regras de pensão por morte.

A supracitada lei também estabeleceu, em seu Artigo 5ㄴ, que os atos praticados com base em dispositivos da MP no 664 deveriam ser revisados de acordo com as regras definitivas estabelecidas na Lei no $13.135 / 2015$. A título de exemplo, as pensóes concedidas com valor de $50 \%+10 \%$ do salário de benefício por cada dependente, de março de 2015 até a sanção da Lei no $13.135 / 2015$, deverão ser revisadas para 100\%.

Do ponto de vista fiscal, portanto, a MP n⿳o 664 foi substancialmente modificada pelo Congresso Nacional, e certamente houve uma diminuição relevante da redução da despesa com o pagamento das pensóes por morte previsto incialmente com a MP nº 664, embora ainda haverá alguma diminuição dos gastos.

Também houve alteraçóes no rol de dependentes, que afetam o pagamento da pensão, em especial em relação às pessoas com deficiência, tanto pela tramitação da MP no 664, quanto pela chamada Lei Brasileira de Inclusão (LBI) ou Estatuto da Pessoa com Deficiência, que foi sancionada pela Lei no 13.146 , de 6 de julho de 2015 . Embora a MP nº 664 náo tratasse de mudanças do rol de dependentes, durante sua tramitação no Congresso Nacional, houve alteração. Antes da MP, o conceito de dependente incluía filhos e irmãos não emancipados menores de 21 anos ou de qualquer idade, desde que inválidos ou com deficiência mental ou intelectual que o tornassem absolutos ou relativamente incapazes, assim declarado judicialmente. Foram aprovadas emendas que excluíram a condicionalidade de que o filho ou irmão não fossem emancipados, bem como no tocante à deficiência, sendo definido, portanto, como dependente o deficiente mental ou intelectual, de qualquer grau, ou deficiente grave. Além de ser questionável a exclusão da condicionalidade de emancipado, em conflito com o código civil, ao excluir da condição de deficiência mental ou intelectual o condicionante de absoluta ou relativamente incapaz, 
assim declarado judicialmente, não apenas se afasta do conceito de incapacidade, como de certa forma pode permitir que qualquer nível de deficiência intelectual possa garantir direito à pensão vitalícia, bem como trata a deficiência como sinônimo de incapacidade.

Na sanção da Lei no $13.135 / 2015$, foi vetada a alteração em relação ao filho, com o argumento de que "a medida acabaria por presumir a dependência econômica de filho emancipado, em conflito com a própria natureza do instituto da emancipação do direito civil". Contudo, foi sancionada a mudança similar para os irmãos mesmo com a previsão de um vacatio legis de seis meses para a deficiência grave e de dois anos para a mental ou intelectual. A alteração, tanto do filho quanto irmão com deficiência mental ou deficiência intelectual ou deficiência grave, foi aprovada para os servidores públicos federais por meio da alteração na Lei noำ 8.112/1990.

Posteriormente, apenas algumas semanas depois da sanção da Lei no 13.135/2015, houve nova mudança com a sanção da LBI ou Lei no $13.146 / 2015$ por ter sido aprovada nova redação que trazia de volta condicionalidade de filhos ou irmãos não emancipados, mas mantendo o direito à pensáo por morte para deficientes mentais ou deficientes intelectuais de qualquer grau e deficientes graves de qualquer idade. Claramente, houve uma ampliação do rol de dependentes para as pessoas com deficiência, com uma clara distorção conceitual ao equiparar, em algum grau e de forma equivocada, deficiência com incapacidade laboral. Ademais, foi revogado o $\$ 4^{\circ}$ do Artigo 77 , que estabelecia uma redução de $30 \%$ da cota individual da pensão por morte de deficiente mental ou deficiente intelectual que passasse a exercer atividade remunerada, bem como garantia o reestabelecimento da integralidade da pensão em caso de fim do exercício da referida atividade remunerada. Com essa revogação, mesmo que o deficiente mental ou intelectual passe a exercer alguma atividade remunerada, não terá a redução de $30 \%$ e poderá manter a sua cota de pensão de forma integral.

$\mathrm{O}$ cenário das regras de pensão por morte anterior à promulgação da $\mathrm{MP} \mathrm{n}$ o 664, que motivou a sua edição, será discutido de forma mais aprofundada na seção Temas em destaque.

Todas as mudanças nas regras de pensão, como período mínimo de contribuiçôes e de casamento e união estável, alteração da duração do benefício para cônjuges e outras também aplicam-se ao auxílio-reclusão, tendo em vista que o Artigo 80 da Lei no 8.213/1991 estabelece que o referido benefício será devido nas mesmas condições da pensão por morte aos dependentes do segurado recolhido à prisão, que não receber remuneração da empresa nem estiver em gozo de auxílio-doença, de aposentadoria ou de abono de permanência. Na realidade, o auxílio-reclusão é um benefício similar à pensão por morte, com a diferença de que no primeiro caso o fato gerador que compromete a capacidade de sustento da família é a reclusão do segurado e, no segundo, a morte do instituidor. 


\subsubsection{Auxílio-doença}

Também houve alterações nas regras do auxílio-doença e na perícia médica. Em primeiro lugar, a MP no 664 propunha duas alteraçôes em relação ao auxílio-doença: i) ampliação do prazo de afastamento, a cargo do empregado, de 15 para 30 dias para o segurado empregado; ii) instituição de um teto para o valor do auxílio-doença que passava a ser a média dos doze últimos salários de contribuição. A primeira proposta foi justificada com o incremento ao longo do tempo da duração dos afastamentos que chegaram a uma média de cerca de oito meses, refletindo a maior participação daqueles decorrentes de doenças ou problemas crônicos. Portanto, era uma medida que alterava a distribuição dos custos dos afastamentos entre o governo e os empregadores. A medida resultaria na transferência de custos do RGPS para os empregadores, sem necessariamente, apresentar prejuízos para os trabalhadores. Contudo, essa medida foi rejeitada pelo Poder Legislativo, provavelmente, em função, entre outros fatores, da resistência patronal à medida.

A instituição para um teto para auxílio-doença era, na realidade, uma proposição legislativa que já tramitava há vários anos no Congresso Nacional e era justificada pelo fato do cálculo do referido benefício, em muitos casos, ficar acima do último salário do trabalhador e, dessa forma, poderia até mesmo ser um desestímulo à volta a atividade. Essa proposta foi aprovada pelo Legislativo e sancionada pelo Poder Executivo.

A MP no 664 também tinha como uma das suas proposiçóes a flexibilização da prestação da perícia médica. A Lei no 10.876, de 2 de junho de 2004, definia como competência privativa dos peritos médicos da Previdência Social o exercício das atividades médico-periciais inerentes ao RGPS. A referida MP excluiu a competência privativa, abrindo a possibilidade de formas alternativas de execução ou prestação desse importante serviço.

A MP nำ 664, além de excluir a competência privativa dos médicos peritos do INSS, alterou a Lei no 8.213 de forma que ficou prevista a possibilidade de que o INSS, a seu critério e sob sua supervisão, poderia realizar perícias médicas: i) por convênio ou acordo de cooperação técnica com empresas; ii) por termo de cooperação técnica firmado com órgãos e entidades públicos, especialmente onde não houver serviço de perícia médica do INSS.

Por um lado, a flexibilização pode ser vista como positiva tendo em vista que a oferta de perícia médica ainda é um gargalo na prestação de serviços do INSS, havendo localidades onde o agendamento de perícia ultrapassava o patamar de cem dias, embora na média o valor fosse inferior a esse patamar. Nesse sentido, ampliar as possibilidades de execução do serviço pode ser visto como um mecanismo para melhorar a qualidade dos serviços públicos. Contudo, por outro lado, a flexibilização levanta algumas preocupaçóes: $i$ ) no passado, a terceirização da perícia resultou em 
um expressivo aumento do estoque de auxílio-doença e, aparentemente, fragilização dos controles da concessão e da despesa com benefícios decorrentes de incapacidade; ii) vários segmentos da sociedade criticaram as alternativas apresentadas, seja pela possibilidade de terceirização ou mesmo pela liberação de perícia por empresas privadas, sendo que, nesse último caso, poderia haver conflito de interesses.

Durante a tramitação dessas alteraçóes na perícia médica, houve resistência em relação às perícias realizadas pelas empresas e à possibilidade de terceirização para o setor privado, em especial, pelas centrais sindicais dos trabalhadores. A versão aprovada pelo Congresso Nacional, que foi para sanção da presidenta da República, estabelecia que nos casos de impossibilidade de realização de perícia médica pelo órgão ou setor próprio competente, assim como de efetiva incapacidade física ou técnica de implementação das atividades e de atendimento adequado à clientela da previdência social, o INSS poderia, sem ônus para os segurados, celebrar, convênios, termos de execução descentralizados, termos de fomento ou de colaboração, contratos não onerosos ou acordos de cooperação técnica para realização de perícia médica, por delegação ou simples cooperação técnica, sob sua coordenação e supervisão, com: i) órgãos e entidades públicos ou que integrem o Sistema Único de Saúde (SUS); ii) entidades privadas de serviço social e de formação profissional, vinculadas ao sistema sindical, ou seja, ao Sistema S; iii) entidades privadas de comprovada idoneidade financeira e técnica, desde que náo empregassem o segurado. Contudo, houve veto a todas alternativas, exceto a prestaçáo do serviço pelo SUS, sendo que a alegação para o veto foi a de que

em decorrência da natureza das perícias médicas tratadas, não caberia atribuí-las a entidades privadas sem as devidas restrições, sendo mais adequado permanecerem no âmbito de órgãos e entidades públicos ou que integrem o Sistema Único de Saúde (SUS).

Portanto, a decisão foi a de manter as perícias no âmbito do setor público.

Mesmo reconhecendo que a flexibilização das possibilidades de execução da perícia seja, a priori, conceitualmente positiva e uma forma de tentar buscar melhorias na qualidade de prestação de serviços e mais celeridade no atendimento dos segurados, é bastante duvidoso que a medida seja amplamente eficaz. Tal prognóstico leva em consideração que o SUS já tem dificuldades para atender a demanda que enfrenta atualmente e, certamente, terá dificuldade para dar conta dessa demanda adicional, até mesmo pela execução altamente descentralizada no âmbito do SUS que dificultará a coordenação com o INSS. De qualquer forma, a medida é uma tentativa válida, que precisará ser avaliada no futuro.

O quadro 1 sintetiza para o benefício de pensão por morte as principais alteraçóes propostas e o resultado após apreciação no Congresso Nacional. 
QUADRO 1

\section{Regras de pensão por morte no Brasil - regra anterior, proposta de reforma paramétrica (MP no 664/2014) e regras aprovadas (Lei no 13.135/2015)}

\begin{tabular}{|c|c|c|c|}
\hline Critério & $\begin{array}{l}\text { Regra antes da } \\
\text { MP no } 664\end{array}$ & Regra da MP no 664/2014 & Regra sancionada pela Lei no 13.135/2015 \\
\hline Carência & $\begin{array}{l}\text { Concessão pensão } \\
\text { por morte independe } \\
\text { de carência. Exigência } \\
\text { apenas da qualidade } \\
\text { de segurado. }\end{array}$ & $\begin{array}{l}\text { Carência de dois anos de } \\
\text { contribuição, exceto para } \\
\text { acidentes do trabalho ou doença } \\
\text { profissional ou do trabalho. } \\
\text { Alteração também estendida para } \\
\text { os servidores públicos federais. }\end{array}$ & $\begin{array}{l}\text { A exigência foi reduzida para dezoito meses de } \\
\text { contribuição, mas foi criado pagamento do benefí- } \\
\text { cio para quatro meses de contribuição para segura- } \\
\text { dos que não cumprissem tal condicionalidade, } \\
\text { além de alteração das exceções para acidente } \\
\text { de qualquer natureza ou de doença profissional } \\
\text { ou do trabalho. Essas alterações também foram } \\
\text { estendidas para os servidores públicos federais. }\end{array}$ \\
\hline $\begin{array}{l}\text { Tempo } \\
\text { mínimo de } \\
\text { casamento } \\
\text { ou união } \\
\text { estável }\end{array}$ & $\begin{array}{l}\text { Não havia exigência } \\
\text { de tempo mínimo } \\
\text { de casamento ou } \\
\text { união estável. }\end{array}$ & $\begin{array}{l}\text { Introdução da exigência de dois } \\
\text { anos de casamento ou união } \\
\text { estável. Exceção se óbito do } \\
\text { instituidor fosse decorrente de } \\
\text { acidente posterior ao casamento } \\
\text { ou união estável ou se o cônjuge } \\
\text { fosse considerado incapaz para } \\
\text { exercício de atividade remunerada } \\
\text { que garantisse a subsistência. } \\
\text { Mudança estendida para os } \\
\text { servidores públicos federais. }\end{array}$ & $\begin{array}{l}\text { Embora tenha sido mantido o período mínimo } \\
\text { de dois anos de casamento ou união estável, } \\
\text { foi criado pagamento por quatro meses de } \\
\text { contribuição para segurado que não cumprir essa } \\
\text { condicionalidade. Exceção para caso de óbito } \\
\text { do instituidor ter sido decorrente de acidente de } \\
\text { qualquer natureza ou doença profissional ou do } \\
\text { trabalho, bem como para cônjuges com invalidez } \\
\text { ou deficiência, casos em que o fim do pagamento } \\
\text { se dá, respectivamente, pela cessação da } \\
\text { invalidez ou afastamento da deficiência. Mudança } \\
\text { estendida para os servidores públicos federais. }\end{array}$ \\
\hline $\begin{array}{l}\text { Duração } \\
\text { do bene- } \\
\text { fício para } \\
\text { cônjuges }\end{array}$ & $\begin{array}{l}\text { Pensão para o } \\
\text { cônjuge era vitalícia, } \\
\text { independentemente } \\
\text { da idade do cônjuge/ } \\
\text { viúvo(a), na data do } \\
\text { óbito do instituidor, } \\
\text { mesmo que sem filhos, } \\
\text { com plena capacidade } \\
\text { laboral e sem depen- } \\
\text { dência econômica, } \\
\text { que é presumida. }\end{array}$ & $\begin{array}{l}\text { Duração do benefício dependeria } \\
\text { da expectativa de sobrevida do } \\
\text { cônjuge na data de óbito do } \\
\text { instituidor, sendo vitalícia para } \\
\text { expectativa de sobrevida de até } \\
35 \text { anos (idade pela tabela atual } \\
\text { de } 44 \text { anos ou mais) e variando } \\
\text { de } 3 \text { a } 15 \text { anos para aqueles } \\
\text { com expectativa de sobrevida } \\
\text { acima de } 35 \text { anos. Atualização } \\
\text { da idade seria anual, de acordo } \\
\text { com publicação de nova tabela } \\
\text { do IBGE. Alteração estendida para } \\
\text { os servidores públicos federais. }\end{array}$ & $\begin{array}{l}\text { Duração foi definida de acordo com a idade } \\
\text { do cônjuge na data de óbito do instituidor, } \\
\text { sendo vitalícia para } 44 \text { anos ou mais de idade } \\
\text { e variando de } 3 \text { a } 20 \text { anos para aqueles com } \\
\text { menos de } 44 \text { anos. Essas faixas passam a ser } \\
\text { atualizadas no mínimo de três em três anos pelo } \\
\text { incremento na expectativa de vida ao nascer ou } \\
\text { quando o referido incremento desse indica- } \\
\text { dor alcançar o mínimo de um ano. Alteração } \\
\text { estendida para os servidores públicos federais. }\end{array}$ \\
\hline $\begin{array}{l}\text { Homicídio } \\
\text { do institui- } \\
\text { dor doloso }\end{array}$ & $\begin{array}{l}\text { Não havia restrição } \\
\text { legal ao recebimento } \\
\text { de pensão para } \\
\text { dependente que } \\
\text { cometesse crime } \\
\text { doloso que resultasse } \\
\text { na morte do instituidor. }\end{array}$ & $\begin{array}{l}\text { Excluía direito à pensão para } \\
\text { o dependente condenado pela } \\
\text { prática de crime doloso que } \\
\text { resultasse na morte do segurado. } \\
\text { Mudança estendida para os } \\
\text { servidores públicos federais. }\end{array}$ & $\begin{array}{l}\text { Foi mantida a perda de direito à pensão para o } \\
\text { dependente condenado pela prática de crime de } \\
\text { que tenha dolosamente resultado na morte do } \\
\text { segurado, mas após trânsito em julgado. Mudança } \\
\text { estendida para os servidores públicos federais. }\end{array}$ \\
\hline $\begin{array}{l}\text { Valor do } \\
\text { benefício }\end{array}$ & $\begin{array}{l}\text { Valor é de } 100 \% \text { da } \\
\text { aposentadoria que o } \\
\text { instituidor recebia ou } \\
\text { que teria direito se } \\
\text { estivesse aposen- } \\
\text { tado por invalidez, } \\
\text { ou seja, } 100 \% \text { do } \\
\text { salário de benefício, } \\
\text { nesse último caso. A } \\
\text { cessação da cota de } \\
\text { um dependente reverte } \\
\text { para os dependentes } \\
\text { remanescentes. }\end{array}$ & $\begin{array}{l}\text { Valor da aposentadoria passava a } \\
\text { ser } 50 \% \text { de cota familiar }+10 \% \\
\text { por dependente da aposenta- } \\
\text { doria que o instituidor recebia } \\
\text { ou que teria direito se estivesse } \\
\text { aposentado por invalidez, mantida } \\
\text { a garantia de salário-mínimo. } \\
\text { Fim da reversão de cotas. }\end{array}$ & $\begin{array}{l}\text { Regras propostas pela MP foram rejeitadas e } \\
\text { foram mantidas as regras anteriores à MP. }\end{array}$ \\
\hline
\end{tabular}


Do ponto de vista fiscal, as alteraçóes efetivas com a Lei no $13.135 / 2015$ realmente terão algum efeito de redução das despesas com pensão por morte e auxílio-doença, mas o impacto foi extremamente reduzido em relação à proposta inicial feita pela MP. Do ponto de vista da proteção social, a MP tinha como efeito corrigir algumas distorçôes como, por exemplo, a possibilidade de comportamentos oportunistas em função da falta de carência e de um tempo mínimo de casamento ou uniāo estável, cujo estímulo foi reduzido, mas não eliminado. Esses aspectos serão discutidos com maior detalhe na seção Temas em destaque.

\subsection{A fórmula 85/95 e a MP no 676/2015}

Durante a tramitação no Congresso Nacional da MP n⿳o 664/14, houve uma importante mudança que foi a aprovação de uma emenda que estabelecia o fator 85/95. Essa alteraçáo corresponde à não aplicação do fator previdenciário quando a soma de idade com o tempo de contribuição, na data de requisição da aposentadoria, atingisse 85 para mulheres, com pelo menos 30 anos de contribuição, e 95 para homens, com pelo menos 35 anos de contribuição.

Os parâmetros de 35 e 30 anos de contribuição estão definidos na Constituição e, portanto, não poderiam ser alterados por lei, ou seja, não foi alterado o critério para concessão da aposentadoria por tempo de contribuição (ATC), mas sim o cálculo do valor do benefício para quem atender a soma de 85/95, com forte incremento do valor de concessão da aposentadoria. A medida, portanto, afeta as chamadas ATCs, que são os benefícios com maior valor no âmbito do RGPS, dando um caráter regressivo a esta alteração, como será mostrado na seção 4. Essa medida, ao elevar de forma significativa o valor das aposentadorias, certamente implica expressivo aumento da despesa do RGPS a médio e longo prazos.

Embora o Poder Executivo tenha vetado essa alteração, na prática houve uma importante mudança, pois, no mesmo momento do veto, houve a promulgação da Medida Provisória no 676, de 17 de junho de 2015, que instituía o fator $85 / 95$ progressivo (de $85 / 95$ para $90 / 100$ até 2022 ). Entretanto, durante a tramitação no Congresso Nacional, foi alterada a velocidade da progressão, tornando-a mais lenta, de tal sorte que o fator 90/100 será alcançado apenas em 31 de dezembro de 2026, ou seja, na prática, apenas em 2027. Com essa modificação, o efeito final das mudanças foi uma piora e não uma melhora da situação fiscal e financeira do RGPS a médio e longo prazos. Haverá um aumento da despesa de caráter regressivo. Esses impactos serão discutidos em maior profundidade na seção Temas em destaque. 


\subsection{A Lei no 13.152/2015 e a política de valorização do salário-mínimo}

Refletindo a fragilidade política do Poder Executivo no Congresso Nacional, durante a tramitação da $\mathrm{MP}$ no $\mathbf{6 7 2}$, que estendia a política de valorização do salário-mínimo para o período de 2016 a 2019, foi aprovada emenda que estendia a regra para todos os benefícios do RGPS acima do salário-mínimo. Na conversão para a Lei no 13.152 , de 29 de julho de 2015, foi sancionada a continuidade da política de valorização do salário-mínimo, para o período de 2016 a 2019, pela regra de reajuste pela inflação acrescido do ganho real pelo crescimento do produto interno bruto (PIB) de dois anos antes, ou seja, para 2016 será considerado o comportamento do PIB em 2014 e assim por diante, até o ano de 2019, quando será considerado o incremento da produção de 2017. A extensão dessa regra para benefícios do INSS, acima do salário-mínimo, foi vetada pelo Poder Executivo. Na manifestação oficial, que justifica o veto, o argumento foi de caráter legal, mais especificamente o inciso IV do Artigo 7o da Constituição, que veda a vinculação ou indexação do salário-mínimo para qualquer fim, exceto seu papel como piso da Seguridade Social.

Embora a justificativa oficial tenha sido pela inconstitucionalidade, a medida certamente teria impacto significativo sobre as contas do RGPS, em especial a médio e longo prazo, representando real ameaça à viabilidade fiscal da política de valorizaçáo do salário-mínimo. A título de exemplo, entre 1995 e 2015, enquanto o salário-mínimo teve um reajuste de $1.025,71 \%$, os benefícios do RGPS, acima do salário-mínimo, tiveram um incremento no mesmo período de $461,70 \%$, uma diferença muito expressiva. Essa referida diferença não significou perda de compra real dos que ganham acima do piso previdenciário, tendo em vista que a alta da inflação, medida pelo índice nacional de preços ao consumidor (INPC), ficou em $384,92 \%$, o que resulta em um ganho real de $15,8 \%$ para os benefícios acima do salário-mínimo. Na realidade, o argumento de perda real está associado muitas vezes à diminuição do valor do benefício em número de salários-mínimos, que na verdade reflete o aumento real do piso e não redução do seu poder de compra.

Fazendo esse mesmo cotejamento para o período de 2003 a 2015, enquanto o piso previdenciário teve um reajuste de $294 \%$, os benefícios acima do salário-mínimo tiveram reajuste de $132,62 \%$ e a inflação medida pelo INPC no período foi de $121,44 \%$ (considerando o intervalo entre reajustes dos benefícios acima do piso). Portanto, esses dados deixam claro que houve uma diferença muito grande entre os reajustes, que refletem os expressivos ganhos reais do salário-mínimo. Nesse sentido, essa extensão da mesma regra que vem sendo aplicada, na prática, desde 2007, tenderia elevar de forma muito significativa os impactos fiscais da política de valorização do salário-mínimo e poderia inviabilizar, do ponto de vista fiscal, um maior ganho real do referido piso legal de remuneração.

Do total de 28,2 milhóes de benefícios do RGPS em junho de 2015, cerca de 9,9 milhóes tinham valor acima do salário-mínimo, o que corresponde a 35,1\% do total. Embora representem cerca de um terço da quantidade total de benefícios, 
em função de seu maior valor médio, acabam por responder por um percentual maior da folha de pagamento do RGPS, respondendo por mais da metade do valor total (cerca de 55\%). Para cada 1\% de aumento dos benefícios acima do salário-mínimo, há um aumento da despesa do RGPS da ordem de cerca de R \$ 2 bilhóes por ano. A estimativa oficial apresentada pelo governo era a de que a aplicação do reajuste do salário-mínimo para todos os beneficiários do INSS implicaria aumento de gastos de R 11 bilhóes até 2019. ${ }^{2}$

Mesmo que o impacto fiscal nos anos de 2016 e 2017 seja muito pequeno, em função da baixa taxa de crescimento econômico ou até mesmo retração, a partir de 2018, poderia haver impacto mais significativo. Uma estimativa apresentada pelo Ministério do Trabalho e Previdência Social é que se a regra já estivesse sendo aplicada desde 2007, quando a atual fórmula de reajuste do salário-mínimo passou a vigorar, no período de 2007 a 2015 o incremento da despesa do RGPS seria da ordem de R \$ 325 bilhóes, sendo R \$ 73,2 bilhóes apenas em 2015. Esses dados deixam claro que o impacto a médio e longo prazo dessa regra seria expressivo e, no limite, comprometeria a viabilidade de qualquer incremento mais relevante do salário-mínimo. Ademais, esse aumento da despesa teria caráter regressivo, tendo em vista que seria direcionado àqueles com maior valor de benefícios.

Conforme mostrado na edição no 23 deste periódico, os benefícios de até um salário-mínimo são progressivos, embora essa progressividade tenha diminuído no período de 2003 a 2012 e, de forma inversa, os benefícios superiores ao salário-mínimo são regressivos, ainda que essa regressividade tenha sido reduzida no referido período.

\subsection{A Lei no 13.161/2015 e a desoneração de folha}

As dificuldades do Poder Executivo no Congresso Nacional também ficaram evidentes na tentativa de reverter a desoneração da folha de pagamentos, que chegou a ser enviada ao Congresso como Medida Provisória no 669, de 26 de fevereiro de 2015, mas foi devolvida pelo presidente do Senado, sem sequer ter sido apreciada pelo Poder Legislativo, e, posteriormente, foi revogada pelo Poder Executivo. A proposta foi novamente enviada pelo Poder Executivo ao Congresso Nacional, sob a forma do Projeto de Lei (PL) no 863, de 20 de março de 2015, tendo sido aprovado pelo Congresso Nacional apenas no final de agosto de 2015 e sancionada pela Lei $\mathrm{n}^{-}$13.161, de 31 de agosto de 2015. A referida lei, em linhas gerais, estabeleceu uma reversão na desoneração da folha de pagamentos ou salários, estabelecendo que as empresas beneficiadas pudessem continuar a pagar a contribuição patronal calculada pela aplicação de uma alíquota sobre o faturamento e não sobre a folha de pagamento, mas que essas alíquotas fossem majoradas de $1 \%$ e $2 \%$, respectivamente, para $2,5 \%$ e $4,5 \%$, sendo que as empresas poderiam optar pela folha de pagamento caso quisessem, em função dessa majoração. 
Certamente, a medida reduzirá de maneira significativa a renúncia fiscal relacionada à desoneração da folha de pagamento e ajudará no ajuste das contas públicas, por meio de aumento da arrecadaçáo. Mas o efeito em 2015 será muito pequeno, tendo em vista que a medida passa a valer em dezembro e, portanto, terá efeito mais significativo a partir de 2016. As estimativas da renúncia fiscal, segundo o Ministério da Fazenda, ${ }^{3}$ eram da ordem de R \$ 21,6 bilhóes (0,39\% do PIB) no ano de 2014 e, em 2015, sem alteração da legislação, de R \$ 25,2 bilhôes. A estimativa, também do Ministério da Fazenda, era que o PL n-863/2015 reduziria a renúncia fiscal em cerca de R \$ 12 bilhóes por ano. ${ }^{4}$

QUADRO 2

Medidas legais relativas à desoneração da folha de pagamentos/salários

\begin{tabular}{|c|c|}
\hline Medida legal & Descrição sintética da medida \\
\hline $\begin{array}{l}\text { MP no540 (2/8/2011) convertida na } \\
\text { Lei no } 12.546(14 / 12 / 2011)\end{array}$ & $\begin{array}{l}\text { Início da substituiçã̃o da alíquota de } 20 \% \text { sobre a folha para 1,5\% } \\
\text { ou 2,5\% sobre o faturamento para poucos setores (Tecnologia da } \\
\text { Informação (TI), Tecnologia da Informação e Comunicação (TIC), } \\
\text { indústrias moveleiras, de confecções e de couro) até dezembro de } 2012 \text {. }\end{array}$ \\
\hline $\begin{array}{l}\text { MP no-563 (3/4/2012) convertida na } \\
\text { Lei no } 12.715(17 / 9 / 2012)\end{array}$ & $\begin{array}{l}\text { Ampliação do prazo para dezembro de } 2014 \text {, bem como dos setores } \\
\text { beneficiados, como, por exemplo, mais setores industriais, ramo hote- } \\
\text { leiro, transporte rodoviário, aéreo e marítimo, bem como manutenção } \\
\text { de aeronaves, com alíquotas sobre faturamento de } 1 \% \text { ou } 2 \% \text {. }\end{array}$ \\
\hline $\begin{array}{l}\text { MP no } 582(20 / 9 / 2012) \text { convertida na } \\
\text { Lei no } 12.794(2 / 4 / 2013)\end{array}$ & Ampliação dos setores industriais. \\
\hline $\begin{array}{l}\text { MP no601 (28/12/2012) teve sua vigên- } \\
\text { cia encerrada, mas foi absorvida pela } \\
\text { Lei no } 12.844 \text { (19/7/2013), que foi uma conversão } \\
\text { da MP no } 610\end{array}$ & $\begin{array}{l}\text { Inclusão de novos setores como comércio varejista, segmentos da } \\
\text { construção civil, reparo de embarcações e mais ramos industriais. }\end{array}$ \\
\hline $\begin{array}{l}\text { MP no } 612 \text { (4/4/2013) teve sua vigência encerrada, } \\
\text { mas foi absorvida pela Lei no } 12.844 \text { (19/7/2013) } \\
\text { que foi uma conversão da MP no } 610\end{array}$ & $\begin{array}{l}\text { Inclusão de novos setores como transporte ferroviário ou metro- } \\
\text { viário de passageiros; transporte rodoviário e ferroviário de carga; } \\
\text { carga e descarga em portos; construção de obras de infraestrutura; } \\
\text { empresa de jornalismo e ampliação dos ramos industriais. }\end{array}$ \\
\hline $\begin{array}{l}\text { MP no634 (26/12/2013) convertida na } \\
\text { Lei no } 12.995(18 / 6 / 2014)\end{array}$ & Ajuste pontual na desoneração. \\
\hline $\begin{array}{l}\text { MP no651 (9/7/2014) convertida na } \\
\text { Lei no } 13.043(13 / 11 / 2014)\end{array}$ & $\begin{array}{l}\text { Excluía o prazo previsto de duração de dezembro de } 2014 \text { da lei, sendo } \\
\text { anunciada como medida que tornava permanente a desoneração. }\end{array}$ \\
\hline $\begin{array}{l}\text { MP no } 669 \text { (26/2/2015) sendo substituída } \\
\text { pelo PL no } 683(20 / 3 / 2015) \text { e convertida na } \\
\text { Lei no } 13.161(31 / 8 / 2015)\end{array}$ & $\begin{array}{l}\text { Permite às empresas optar pela volta da contribuição patronal previdenciá- } \\
\text { ria de } 20 \% \text { sobre folha ou manter com alíquota de faturamento majoradas } \\
\text { de } 1 \% \text { ou } 2 \% \text { para, respectivamente, } 2,5 \% \text { ou } 4,5 \% \text { sobre o faturamento. }\end{array}$ \\
\hline
\end{tabular}

Elaboração dos autores.

A desoneração da folha tem suscitado grande debate na opinião pública, inclusive, pela forma como foi implementada, por meio de uma sucessão de medidas provisórias sem um debate junto à sociedade e com o próprio Congresso Nacional, bem como sem uma adequada avaliação dos impactos em termos de custo/benefício ou de critérios objetivos/transparentes para seleção dos setores beneficiados.

3. Essas estimativas constam da Nota Considerações Sobre o Projeto de Lei nº863/2015 - Desoneração da Folha de Pagamento do Ministério da Fazenda.

4. Houve alterações do projeto original no Congresso Nacional. 
A referida medida acabou contribuindo para deterioração das contas públicas, sem aparentemente ter gerado benefícios mais relevantes.

O total de contribuintes beneficiados estava em torno de 85 mil, que correspondia a apenas $4,5 \%$ dos estabelecimentos não optantes do Sistema Integrado de Pagamento de Impostos e Contribuiçóes das Microempresas e Empresas de Pequeno Porte (Simples) que apresentaram o Guia de Recolhimento do Fundo de Garantia do Tempo de Serviço - FGTS (GFIP), mas respondiam por 19,6\% da arrecadação total, inclusive do Simples, em especial, nos setores de construção civil, comércio varejista e tecnologia da informação (53\% dos contribuintes beneficiados).

Do ponto de vista da Previdência Social, há várias críticas que precisam ser feitas a respeito da desoneração da folha de pagamento e sua substituição parcial pela contribuição sobre faturamento.

O termo parcial está colocado para enfatizar que as alíquotas sobre o faturamento que foram estabelecidas eram insuficientes para repor toda arrecadação gerada pela alíquota de $20 \%$ sobre a folha. Em primeiro lugar, a função precípua da contribuiçáo sobre a folha deveria ser a de garantir o adequado financiamento das despesas com benefícios da Previdência Social. A tradicional vinculação com a folha de salários explica-se pelo fato de que o valor dos benefícios é vinculado aos salários. Portanto, a medida realmente diminui o necessário vínculo entre contribuiçōes e benefícios.

A alíquota de $20 \%$ sobre a folha não decorre de um desejo premeditado de prejudicar a competitividade ou tornar mais caro o emprego formal, mas sim da necessidade de financiar os gastos com Previdência Social. Na verdade, a desoneração deveria ter deixado mais clara, para a sociedade e para o governo, a necessidade de discutir de forma mais profunda os custos e benefícios de nosso sistema de proteção social, seus efeitos distributivos e como garantir um adequado sistema de financiamento que seja, concomitantemente, suficiente, em termos de arrecadação, e que busque minimizar ou mesmo evitar eventuais efeitos negativos sobre a eficiência, a competitividade e o emprego. Nesse sentido, eventuais tentativas de obter ganhos de competitividade e de estimular geração de empregos formais não podem obscurecer ou mesmo ameaçar a necessidade de um sistema de financiamento sólido do sistema de proteção social. Embora a desoneração tenha sido desenhada com compensação do Tesouro ao Fundo do Regime Geral, de forma a não afetar o resultado do RGPS, na prática essa compensação tem caráter contábil, no sentido que existe uma renúncia fiscal que piora as contas públicas e aumenta a dependência do RGPS em relação aos repasses do Tesouro. Contudo, cabe destacar que há várias outras renúncias previdenciárias, como Simples, exportação rural, para entidades filantrópicas e outras, para as quais não há nem essa compensação de caráter contábil. 
Outra importante crítica em relação à substituição da folha pelo faturamento é que esta última é uma base tributária muito mais instável que a massa salarial, de tal sorte que, em momentos de retração da atividade econômica, se pode esperar uma maior e mais rápida queda na arrecadação, bem como se trata de um tributo em cascata. A desoneração também ajudou a aumentar a já elevada complexidade do sistema tributário brasileiro, inclusive, com possíveis efeitos negativos sobre a fiscalização, pois para uma mesma empresa havia a possibilidade de parte da produção ser pela folha e outra parte pelo faturamento, além de diferentes alíquotas entre setores no lugar de uma mesma alíquota de $20 \%$ sobre a folha para todos os segmentos.

Embora fuja do escopo desta análise uma avaliação mais profunda, cabe mencionar que há muita polêmica a respeito dos impactos da desoneraçâo sobre a distribuição de renda e sobre o emprego formal. Existem estudos, por um lado, que apontam efeitos regressivos e impactos incertos sobre o emprego formal. ${ }^{5}$ Por outro lado, o estudo de Scherer (2015) aponta efeitos positivos da desoneraçáo sobre o emprego formal, ainda que o custo por emprego gerado seja relativamente alto.

\subsection{Regulamentação da EC no 72/2013 sobre o trabalho doméstico ${ }^{6}$}

Depois de mais de dois anos após a aprovação da Emenda Constitucional no 72/2013, que praticamente igualou os direitos dos trabalhadores domésticos com os dos demais trabalhadores, a referida emenda foi regulamentada pela Lei Complementar no $150 / 2015$. Essa regulamentação era importante, pois parte dos direitos estendidos aos trabalhadores domésticos dependiam da regulamentação para se tornarem efetivos, tanto trabalhistas quanto previdenciários.

Nessa lei complementar, o Congresso também decidiu pela redução da alíquota do empregador doméstico de $12 \%$ para $8 \%$, embora tenha instituído contribuição de $0,8 \%$ para seguro contra acidentes do trabalho. Na prática, a contribuição do empregador doméstico para o RGPS caiu de $12 \%$ para $8,8 \%$, ou seja, uma queda líquida de 3,2\%, que foi destinada ao FGTS como forma de provisão mensal para pagamento da multa. Portanto, o Congresso Nacional evitou aumentar o custo para empregador, compensando o aumento com o FGTS pela reduçáo da contribuição para Previdência.

Esse movimento é claramente paradoxal, pois, em um momento que haverá incremento da despesa do RGPS devido à legítima extensão do direito ao salário-família para os trabalhadores domésticos, o Congresso aprova e o Executivo sanciona uma redução da alíquota de contribuição previdenciária para

5. Ver: a) nota Considerações sobre o Projeto de Lei $n$ ㅇ 863/2015 - Desoneração da folha de pagamento do Ministério da Fazenda; b) A desoneração da contribuição patronal sobre a folha de pagamentos - uma solução a procura de problemas de Luis Paiva e Graziela Ansiliero em Planejamento e Políticas Públicas de jan./jun. de 2009; c) Texto para Discussão do Ipea no 1.341, de julho de 2008: A desoneração da folha de pagamentos e sua relação com a formalidade no mercado de trabalho de Graziela Ansiliero, Leonardo Rangel, Luis Paiva, Matheus Stivali e Edvaldo Barbosa.

6. Tal tema também é abordado nos capítulos de Trabalho e renda e no de Igualdade de gênero deste periódico. 
o empregador doméstico. A redução da alíquota de $12 \%$ para $8 \%$ deve gerar uma queda na arrecadação do RGPS da ordem de cerca de $\mathrm{R} \$ 700$ milhóes por ano, para valores de 2015. De outro lado, a legítima extensão para os trabalhadores domésticos deve elevar a despesa do RGPS em cerca de R \$ 240 milhóes por ano, considerando os valores das cotas de 2015.

\section{ACOMPANHAMENTO DA POLÍTICA E DOS PROGRAMAS}

As informações da presente seção utilizarão indicadores estatísticos entre 2005 e 2015, a depender da sua disponibilidade, para o Regime Geral de Previdência Social (RGPS), que cuida da proteção aos trabalhadores da iniciativa privada, empresas de economia mista e parte dos funcionários municipais. Além disso, a seção inclui informaçōes sobre os Regimes Próprios de Previdência Social (RPPS) que cobrem os servidores públicos federais, das unidades da federação e de parte dos municípios. Por fim, será analisado o Regime de Previdência Complementar Fechado (RPC), incluindo os trabalhadores que possuem planos patrocinados por seus empregadores para complementar os planos da previdência social.

A seção que se inicia terá dois tópicos distintos, a saber:

- Evolução dos benefícios do sistema previdenciário; e,

- Perfil de contribuintes e beneficiários.

\subsection{Evolução dos benefícios previdenciários no período recente}

Vale destacar que a previdência no Brasil inclui diversos regimes que possuem importantes dimensôes econômicas e atuam de forma autônoma. O conteúdo incluirá informaçóes referentes ao perfil dos benefícios para:

- o Regime Geral de Previdência Social (RGPS);

- os Regimes Próprios de Previdência dos Servidores Públicos (RPPS); e

- os Regimes de Previdência Complementar Fechada (RPC).

As fontes centrais de informaçóes serão: o Anuário Estatístico da Previdência Social (Aeps) e o Boletim Estatístico da Previdência Social (Beps), que serão complementados pelo Boletim Estatístico de Pessoal do governo federal e pelo Consolidado Estatístico da Associação Brasileira das Entidades Fechadas de Previdência Complementar (Abrapp).

Ao considerar o RGPS, com base em informaçôes do Beps, cuja elaboração é de responsabilidade do Ministério do Trabalho e Previdência Social (MTPS), é possível obter o que existe de mais atualizado sobre o perfil de benefícios. Os indicadores apresentam a evolução em relação aos anos de 2005, 2014 e 2015. Os resultados foram apresentados na tabela 1 . 
TABELA 2

Distribuição e variação percentual entre 2005 e 2015 dos benefícios do RGPS pagos pelo INSS por espécie

\begin{tabular}{lccccc}
\hline \multirow{2}{*}{ Benefícios por espécie } & 2005 & 2014 & 2015 & \multicolumn{2}{c}{ Variação de 2015 para } \\
\cline { 5 - 6 } & & & & 2014 & 2005 \\
\hline Previdenciários & 96,4 & 96,9 & 97,0 & 1,4 & 34,1 \\
Aposentadorias & 61,7 & 64,5 & 65,1 & 1,0 & 40,6 \\
Idade & 31,6 & 34,2 & 34,5 & 1,0 & 45,7 \\
Invalidez & 12,6 & 11,4 & 11,4 & 1,0 & 20,0 \\
Tempo de contribuição & 17,5 & 18,9 & 19,2 & 1,0 & 46,2 \\
Pensões por morte & 27,3 & 26,3 & 26,2 & 1,0 & 28,1 \\
Auxílios & 7,2 & 5,8 & 5,5 & 1,0 & 1,4 \\
Doença & 7,1 & 5,4 & 5,1 & 0,9 & $-3,6$ \\
Acidente & 0,1 & 0,2 & 0,2 & 1,1 & 443,2 \\
Reclusão & 0,1 & 0,2 & 0,2 & 1,0 & 142,9 \\
Salário-maternidade & 0,2 & 0,3 & 0,2 & 0,6 & 24,3 \\
Acidentários & 3,6 & 3,1 & 3,0 & 1,0 & 12,0 \\
Aposentadorias por invalidez & 0,7 & 0,7 & 0,7 & 1,0 & 40,0 \\
Pensão por morte & 0,6 & 0,4 & 0,4 & 1,0 & $-10,5$ \\
Auxílio-doença & 0,6 & 0,6 & 0,6 & 0,9 & 24,2 \\
Auxílio-acidente & 1,3 & 1,1 & 1,1 & 1,0 & 18,7 \\
Auxílio-suplementar & 0,4 & 0,2 & 0,2 & 0,9 & $-37,7$ \\
Total & 100,0 & 100,0 & 100,0 & 1,0 & 33,3 \\
\hline
\end{tabular}

Fonte: Boletim Estatístico da Previdência Social (Beps).

Obs.: Posição em dezembro (novembro para 2015).

De acordo com a tabela 2 , os benefícios previdenciários são os que predominam. Seu aumento de participação de $61,7 \%$ para $65,1 \%$ deve-se ao acréscimo de aposentadorias por idade e tempo de contribuição, sobretudo, tendo em vista que a queda de participação entre os acidentários merece atenção. A queda de incidência para benefícios acidentários pode estar refletindo os efeitos do aumento da parcela de trabalhadores inseridos em atividade de comércio e serviços, cujos riscos são menores que os da agricultura e, sobretudo, da indústria, reduzindo os acidentes de trabalho ou de trajeto, que integram essa categoria de 3,6\% para 3\%. Além disso, conforme apontaram Matijascic e Kay (2014) foram adotadas políticas para a prevenção de acidentes de trabalho com foco em fiscalização e incentivos, com impacto na redução das despesas. Por último, vale notar uma redução de $7,2 \%$ para $5,5 \%$ dos auxílios não acidentários o que se deve, em grande medida, ao envelhecimento da população entre 2005 e 2015 . Vale destacar que as diferenças anuais, no caso da previdência, são muito pequenas, pois os beneficiários tiveram os seus benefícios concedidos ao longo dos anos e somente períodos mais 
extensos permitem observar mudanças do perfil de distribuição dos beneficiários, conforme apontou a tabela 1.

A crise econômica dos anos 1980 e 1990 limitou a elegibilidade às aposentadorias por tempo de contribuição e esse movimento foi reforçado pela Emenda Constitucional no 20 de 1998, que dificultou o acesso e diminuiu a sua taxa de reposição em idades inferiores a 65 anos. O aumento verificado após 2005 reflete, em parte, uma melhoria do acesso a empregos que respeitam os direitos sociais, ou seja, empregos nos quais existe contribuiçâo para a previdência. Como contrapartida, houve uma elevação na participação das aposentadorias por idade.

A queda na participação das pensões por morte deve-se, em grande medida, ao fato de haver mudanças no perfil familiar, em que a mulher não mais depende do homem e o casamento perde destaque na forma de organização das famílias. Com isso, as mulheres passaram a receber com maior frequência aposentadorias, e não basicamente pensão por morte, o que reduziu a participação relativa desses benefícios. Por fim, não é possível esquecer que, com o envelhecimento, outros benefícios passam a ocupar um lugar mais destacado, diminuindo o impacto das pensóes por morte.

Ao considerar os RPPS em suas diferentes esferas de governo e separando os municípios das capitais e do interior, é possível obter, também, um perfil dos beneficiários. Cabe sublinhar que esse perfil não dispõe dos mesmos detalhes que o do RGPS, conforme atesta a tabela 2 .

TABELA 3

Distribuição percentual de benefícios por tipo de segurado nos RPPS

\begin{tabular}{|c|c|c|c|c|c|c|c|c|c|c|}
\hline \multirow{2}{*}{ Segurados } & \multicolumn{2}{|c|}{ Federal } & \multicolumn{2}{|c|}{ Estaduais } & \multicolumn{2}{|c|}{ Capitais } & \multicolumn{2}{|c|}{ Interior } & \multicolumn{2}{|c|}{ Total } \\
\hline & 2005 & 2013 & 2005 & 2013 & 2005 & 2013 & 2005 & 2013 & 2005 & 2013 \\
\hline Inativo & 55,3 & 57,8 & 70,7 & 73,0 & 75,2 & 75,9 & 50,0 & 75,9 & 63,9 & 77,1 \\
\hline Pensionista & 44,7 & 42,2 & 29,3 & 27,0 & 27,8 & 24,1 & 50,0 & 24,1 & 36,1 & 22,9 \\
\hline Total & 100,0 & 100,0 & 100,0 & 100,0 & 100,0 & 100,0 & 100,0 & 100,0 & 100,0 & 100,0 \\
\hline
\end{tabular}

Fonte: Anuário Estatístico da Previdência Social (Aeps) e Boletim Estatístico de Pessoal do Ministério do Planejamento, Desenvolvimento e Gestão (MP) para a esfera federal de governo.

A tabela 3 apresenta um número de informaçóes reduzido, porém essas informações merecem atenção. A proporção entre inativos e pensionistas é crescente ao analisar as esferas federal, estaduais, de municípios, das capitais e do interior. Esse amadurecimento, ou seja, a elevação relativa do acesso a benefícios devido ao envelhecimento e ao cumprimento das carências legais reflete-se na redução da proporção das pensões por morte. A parcela das pensões por morte no RPPS federal é substancialmente superior à parcela das demais esferas, representando mais do que o dobro em termos de proporção. A questão do amadurecimento, aliada às regras 
de concessão que ainda são generosas, explicam a sua importância em relação ao contingente total. Mais adiante, o tema será analisado detalhadamente neste capítulo.

Ao focalizar os RPC é possível apresentar informaçóes que são menos detalhadas que as existentes para o RGPS, mas melhores que as disponíveis para o RPPS. A tabela 3 apresenta os indicadores para os Regimes de Previdência Complementar (RPC).

\section{TABELA 4}

Distribuição percentual de gastos por tipo de segurado nos RPC

\begin{tabular}{lrrc}
\hline Beneficiários & 2005 & 2014 & 2015 \\
\hline Programada & 83,5 & 70,0 & 70,7 \\
Invalidez & 4,9 & 7,9 & 7,7 \\
Pensões & 11,6 & 22,1 & 21,6 \\
Total & 100,0 & 100,0 & 100,0 \\
\hline
\end{tabular}

Fonte: Consolidado Estatístico Abrapp.

Ao analisar os dados da tabela 4 é possível verificar que existem diferenças importantes entre os fundos de pensão dos RPC e o RGPS ou dos RPPS. O principal destaque é a parcela menor da participação das pensóes por morte sobre o total de benefícios em 2005 e a sua elevação desde então. Esse crescimento, sem dúvida, guarda relação com o amadurecimento do sistema que está em curso, mas num estágio anterior ao do RGPS ou do RPPS federal, cuja antiguidade é maior.

Outro aspecto relevante diz respeito ao fato da maioria dos benefícios pagos estar relacionada aos fundos de empresas públicas, de economia mista do governo federal ou que tenham tido esse tipo de situação patrimonial até os anos 1990. A maioria desses fundos foi constituída nos anos 1960 e 1970 com a adoção de planos de benefício definido com um rol de benefícios similar ao existente no RGPS. Os fundos de pensão que foram criados após os anos 1990 tenderam a adotar planos de contribuição definida ou mista e muitos não oferecem a cobertura de pensóes por morte para o cônjuge, limitando-se aos filhos, conforme apontaram Matijascic e Kay (2008). Assim, como os planos ainda não amadureceram o efeito da concessão de benefícios em suas finanças, ainda não afetam de forma destacada as RPC.

Para arrematar, os gastos com benefícios por invalidez nos RPC revelam-se modestos e em proporção inferior ao do RGPS, com um total de 7,7\% em 2013 contra 11,4\% em 2015. Como a invalidez é risco e não depende apenas do perfil etário, sua inserção deveria ser elevada em um sistema imaturo sob o prisma atuarial como o dos RPC, mas não é o que ocorre. Isso deixa entrever que essas empresas, em muitos casos, apresentam baixos riscos para acidentes de trabalho e contam com empregados cujo perfil de saúde não estimula a aposentadoria precoce em razão de doença. Cabe destacar, ainda, que as políticas para promover a saúde e reduzir acidentes de trabalho podem exercer um papel positivo nesse âmbito. 
Ao considerar as diferentes dimensões dos pagamentos de benefícios da previdência nos diferentes regimes, é possível obter informaçóes sobre os gastos e quanto eles representam para a economia brasileira. A tabela 5 apresenta o total de despesas com prestaçóes para beneficiários em relação ao PIB.

TABELA 5

Percentual das despesas com benefícios pagos em dinheiro, por regime em relação ao PIB, em anos selecionados para o Brasil

\begin{tabular}{lccc}
\hline Regime Previdenciário & 2005 & 2013 & 2014 \\
\hline RGPS & 6,7 & 6,0 & 7,1 \\
RPPS & 4,1 & 3,7 & 3,81 \\
RPC & 0,7 & 0,4 & 0,7 \\
Total & $\mathbf{1 1 , 6}$ & $\mathbf{1 0 , 1}$ & $\mathbf{1 1 , 6}$ \\
\hline
\end{tabular}

Fonte: Aeps, MPOG, Associação Brasileira das Entidades Fechadas de Previdência Complementar (Abrapp) e IBGE (vide tabelas anteriores). Nota: ${ }^{1}$ Valor preliminar estimado para 2014.

Ao observar os indicadores apresentados na tabela 5, a evolução dos gastos sobre o PIB foi decrescente entre 2005 e 2013, por sua vez, cresce bastante entre 2013 e 2014. Esses indicadores referem-se a populaçóes numerosas e que se associam à condição de beneficiário após cumprir carências. No mais, é importante destacar que essa redução de participação em relação ao PIB até 2013 deve-se em parte à evolução dos RPPS, que foram afetados por reformas constitucionais em 1998 e em 2003. Além disso, como o período entre 2005 e 2013 foi de crescimento econômico mais acelerado, resultou em uma redução dos gastos como proporção do PIB. Vale destacar que o crescimento de despesas previdenciárias é uniforme, ao passo que o da economia oscila bem mais, afetando de forma decisiva o indicador.

Em termos atuariais, a inserção de beneficiários em um contingente populacional muito elevado é previsível e passível de predição em termos da técnica do seguro social. Diante disso, a previsibilidade do crescimento, associada ao melhor desempenho da economia ao longo desse período explica a redução das despesas em relação ao PIB para o Brasil de 2005 a 2013, reduçáo essa que afetou todos os regimes de previdência. Isso levando em consideração a forte recuperação do poder de compra do salário-mínimo e o amplo destaque dado a essa realidade ao longo dos diversos capítulos da presente publicação. A reversão das condições favoráveis para o crescimento do PIB tende a elevar a participaçáo das despesas com benefícios da previdência em relação a este indicador, o que já parece ser uma tendência observável ao notar a evolução dos indicadores entre 2013 e 2014.

Em síntese, os diferentes regimes de previdência existentes no Brasil apresentam resultados e informaçóes diferenciadas que dificultam uma comparação detalhada. $\mathrm{O}$ amadurecimento atinge os RGPS e o RPPS federal. Isso implica maiores concessóes de benefícios, e um cenário similar aguarda os demais RPPS e o RPC no futuro. 
A divulgação de informaçóes mais detalhadas pelos RPPS e RPC poderia ajudar a promover um debate de maior qualidade e a comparabilidade entre regimes ao publicar informaçóes similares às do RGPS.

\subsection{Perfil de contribuintes e beneficiários}

No tópico anterior, o foco analítico foi centrado nos benefícios e em sua distribuição. Esse foco permitiu obter um perfil, ainda que desigual por tipo de regime, sobre a cobertura de riscos. No entanto, no caso brasileiro, um indivíduo pode ter mais de um benefício ou ser contribuinte e beneficiário ao mesmo tempo. Assim, para apreender como se dá o perfil da população nos diferentes momentos de sua inserção na seguridade, ou seja, como contribuinte ou como beneficiária é necessário atentar para a condição de segurado do indivíduo. A abordagem proposta também apresenta limites, pois não é possível detalhar a inserção por tipo de benefício e incluir os benefícios de prestação continuada da assistência social, não discernindo, ainda os diferentes regimes. Por outro lado, é possível destacar alguns aspectos como o perfil de renda e faixa etária, o que pode ser um problema para o foco em benefícios, pois apenas um beneficiário pode ter dupla contagem nas condiçóes brasileiras. Esse é um limite incontornável quando a base de dados é a Pesquisa Nacional por Amostra de Domicílios - Pnad/IBGE.

Em relação ao perfil etário e ao de renda dos contribuintes e beneficiários, as informaçóes tomaráo por base a Pnad/IBGE, que trata os contribuintes, aposentados e pensionistas de forma agregada e não diferencia por tipo de regime ou espécie de benefício. A tabela 6 apresenta os dados para contribuintes e não contribuintes segundo os diferentes regimes de previdência pública.

Ao observar as informaçóes contidas na tabela 6 , é preciso destacar que não existem informaçôes para os RPC. Isso se deve ao fato de os participantes de RPC serem, necessariamente, segurados de regimes previdenciários públicos. A inserção de informaçóes para esse grupo implicaria dupla contagem quando o perfil dos indivíduos representar o foco analítico. Nesse caso, vale destacar, a chamada previdência aberta, oferecida para o público em geral e não somente para os trabalhadores de uma empresa, como as Entidades Fechadas de Previdência Complementar (EFPC), não integram o sistema previdenciário brasileiro e são reguladas pela Superintendência de Seguros Privados (Susep), no âmbito do Ministério da Fazenda. As informaçóes da tabela 7 são de grande relevância para o estudo da previdência, pois, ao focalizar o período entre 2005 e 2014, foi selecionado um conjunto de anos com um crescimento econômico mais alentado que o dos anos 1980 ou 1990.

A primeira informação a reter é a importante redução do contingente total de não contribuintes sobre a população ocupada, que era majoritário em 
2005 e reduziu de 51\%, em 2005, para 37,7\%, em 2014. Assim, ficou evidente ser o desempenho econômico o principal elemento para explicar a elevação da participação de contribuintes sobre a população ocupada. Em outras palavras, um desempenho melhor da economia medido pelo crescimento do PIB é um elemento fundamental para conter os gastos com previdência em relação a esse mesmo PIB. A criação de legislação específica do Sistema Integrado de Pagamento de Impostos e Contribuiçôes das Microempresas e Empresas de Pequeno Porte (Simples) e para os Microempreeendedores Individuais (MEI) também estimulou decididamente a formalização das atividades das empresas. Isso implicou maior formalização das relaçóes de trabalho em termos de contribuição para a previdência, que não podem ser ignoradas no presente contexto.

TABELA 6

Percentual de contribuintes e não contribuintes da previdência social da população com 16 anos ou mais por regimes previdenciários e posição na ocupação em relação à população ocupada

\begin{tabular}{lccc}
\hline Regimes previdenciários e condição de contribuição & 2005 & 2013 & 2014 \\
\hline Total de regimes de servidores públicos & 6,5 & 7,5 & $\mathbf{7 , 3}$ \\
Assalariados não domésticos & 32,0 & 40,4 & 39,7 \\
Assalariados domésticos & 2,3 & 2,7 & 2,7 \\
Conta própria & 3,2 & 5,2 & 5,9 \\
Empregadores & 2,5 & 2,6 & 2,7 \\
Outros contribuintes & 2,5 & 3,6 & 3,9 \\
Total para contribuintes via regime geral (INSS) & 42,4 & 54,6 & 54,9 \\
Não contribuintes assalariados não domésticos & 15,2 & 11,3 & 11,0 \\
Não contribuintes assalariados domésticos & 5,4 & 3,9 & 3,8 \\
Não contribuintes conta-própria & 18,8 & 15,5 & 15,6 \\
Não contribuintes empregadores & 1,9 & 1,2 & 1,1 \\
Não contribuintes - outros & 9,7 & 6,0 & 6,3 \\
Total de não contribuintes & $\mathbf{5 1 , 0}$ & 37,8 & $\mathbf{3 7 , 7}$ \\
Sem Informação & 0,1 & 0,0 & 0,1 \\
Total de Ocupados & 100,0 & 100,0 & $\mathbf{1 0 0 , 0}$ \\
\hline
\end{tabular}

Fonte: Pnad/IBGE (vários anos).

Elaboração do Núcleo de Informações Sociais (Ninsoc/Disoc) do Ipea.

Outro aspecto relevante para explicar o aumento do número de contribuintes da previdência entre 2005 e 2014 foi o aumento do contingente de assalariados, que representa, em qualquer país, o público-alvo da previdência. Os assalariados não domésticos contribuintes para a previdência representavam $32 \%$, em 2005, e passaram a representar 39,7\%, em 2014. Um número elevado de conta-própria e de domésticos está sempre associado a graus mais elevados 
de não cobertura da previdência. Assim, o aumento da proporção dos assalariados em relação aos demais ocupados é um fator decisivo para explicar a dinâmica do período, incluindo aí aqueles que passam a integrar os RPPS.

No entanto, é preciso ressaltar que o maior nível de atividade econômica entre 2005 e 2014 traduziu-se em um aumento da incidência de contribuintes para as demais posiçôes de ocupação, ou seja, empregados domésticos, empregadores e, especialmente, os conta-própria, o que é relevante e revela a importância da legislação referente aos MEI.

Os dados apresentados na tabela 6 não permitem discernir os servidores dos RPPS por esfera de governo, cuja distinção é relevante para o contexto brasileiro. A tabela 7 apresenta a distribuição dos RPPS por esfera de governo no Brasil.

TABELA 7

Distribuição percentual de segurados por tipo de RPP, segundo a esfera de governo no Brasil, em anos selecionados

\begin{tabular}{|c|c|c|c|c|c|c|c|c|c|c|}
\hline \multirow{2}{*}{$\begin{array}{l}\text { Tipo de } \\
\text { servidor }\end{array}$} & \multicolumn{2}{|c|}{ Federal } & \multicolumn{2}{|c|}{ Estaduais } & \multicolumn{2}{|c|}{ Capitais } & \multicolumn{2}{|c|}{ Interior } & \multicolumn{2}{|c|}{ Total } \\
\hline & 2005 & 2013 & 2005 & 2013 & 2005 & 2013 & 2005 & 2013 & 2005 & 2013 \\
\hline Ativo & 18,4 & 19,4 & 50,0 & 48,8 & 9,1 & 7,3 & 22,4 & 24,5 & 100,0 & 100,0 \\
\hline Inativo & 27,6 & 23,4 & 56,6 & 59,6 & 8,0 & 7,0 & 7,8 & 10,1 & 100,0 & 100,0 \\
\hline Pensionista & 39,3 & 38,3 & 41,4 & 51,2 & 5,5 & 3,3 & 13,8 & 7,2 & 100,0 & 100,0 \\
\hline Total & 23,3 & 22,6 & 50,4 & 51,9 & 8,4 & 6,8 & 17,9 & 18,8 & 100,0 & 100,0 \\
\hline
\end{tabular}

Fonte: Aeps e MP (Boletim Estatístico dos Servidores).

A tabela 7 ao apresentar a distribuição de servidores por esfera de governo permite complementar os dados da tabela 6 . Essa informação foi necessária porque na tabela 6 os dados eram da Pnad e, ao buscar separar os contribuintes dos RPPS por esfera de governo, acontecia uma inconsistência na distribuição com uma presença maior da esfera federal em relaçáo que náo encontra ressonância ao analisar os registros administrativos. Como a Pnad é uma amostragem com resultados baseados em declaraçóes dos respondentes, é possível haver um erro de compreensão para os respondentes que modifica o resultado em termos de distribuição. Apesar disso, ao agregar os RPPS na Pnad, é possível traçar perfis etários e de rendimento, o que seria impossível realizar com base nos dados divulgados pelos registros administrativos dos RPPS. Por fim, vale destacar que os registros administrativos permitem determinar o número de inativos e pensionistas por RPPS, o que não é possível obter com dados da Pnad.

A tabela 6 revela haver uma tendência a reduzir a participação da esfera federal e das capitais cuja contrapartida é o aumento da participação estadual e de municípios do interior para atuar em serviços públicos, sobretudo os sociais como 
é o caso da saúde e da educação. Embora as mudanças sejam moderadas, por se tratar de variáveis estocásticas, é possível perceber, de acordo com esse universo, o aumento da importância das açóes locais para as políticas públicas, com destaque para a esfera social.

A elevação do total de contribuintes em relação à população ocupada pode ser observada em outros focos analíticos. A tabela 8 apresenta indicadores com base nas faixas etárias da população ocupada.

TABELA 8

Percentual de contribuintes e não contribuintes da previdência social por faixas etárias em relação à população ocupada

\begin{tabular}{llllllll}
\hline \multirow{2}{*}{ Faixa etária } & \multicolumn{3}{c}{ Contribuintes } & & \multicolumn{3}{c}{ Não contribuintes } \\
\cline { 2 - 3 } \cline { 7 - 8 } & 2005 & 2013 & 2014 & & 2005 & 2013 & 2014 \\
\hline 16 a 29 & 47,8 & 63,2 & 62,8 & & 52,2 & 36,8 & 37,2 \\
30 a 49 & 54,6 & 66,7 & 67,0 & & 45,4 & 33,3 & 33,0 \\
50 a 64 & 42,8 & 56,6 & 58,4 & & 57,2 & 43,4 & 41,6 \\
65 ou mais & 14,1 & 22,4 & 21,7 & & 85,9 & 77,6 & 78,3 \\
Total & 49,0 & $\mathbf{6 2 , 2}$ & $\mathbf{6 2 , 3}$ & & $\mathbf{5 1 , 0}$ & $\mathbf{3 7 , 8}$ & $\mathbf{3 7 , 7}$ \\
\hline
\end{tabular}

Fonte: Pnad/IBGE (vários anos).

Elaboração do Núcleo de Informações Sociais (Ninsoc/Disoc) do Ipea.

Segundo a tabela 8 , em todas as faixas etárias, houve uma nítida elevação do número de contribuintes em relação aos não contribuintes entre 2005 e 2013. Em 2014, esse movimento altera-se e apresenta uma ligeira retração até os 30 anos de idade, sendo compensado por aqueles que possuem entre 50 e 64 anos. A proporção de contribuintes sempre foi mais elevada entre 30 e 49 anos de idade, ou seja, o auge da idade ativa. $\mathrm{O}$ número mais reduzido de contribuintes após os 50 anos de idade e, sobretudo, após os 65 anos de idade, deve-se ao fato de parte desse contingente ter passado para a condição de aposentado ou pensionista. $\mathrm{O}$ aspecto mais relevante dos dados apresentados na tabela 8 foi a elevaçáo do contingente de contribuintes em relação ao de não contribuintes, que foi importante em todas as idades, mas revelou-se mais sólido entre os mais jovens.

Os dados evocados para faixas etárias mostram-se ainda mais agudos quando o foco são as faixas de rendimentos em múltiplos do salário-mínimo de 2014, que foram apresentados na tabela 9.

Ao focalizar a condição de contribuinte para a previdência pública por faixa de rendimento na tabela 9, é possível afirmar que o aumento da condição de contribuinte em relação à de não contribuinte foi verificado em todas elas, sem nenhuma exceção entre 2005 e 2014 . Em outras palavras a melhoria da situação econômica beneficiou a todos. Porém, o fato de rendimentos com valores 
mais baixos, com destaque para aqueles equivalentes ou inferiores ao salário-mínimo, concentrar o maior número de náo contribuintes ainda não foi alterado. Isso significa que o combate à precarização das relaçóes de trabalho precisa manter o foco na questão relativa ao valor dos rendimentos e denota que a elevação do poder de compra do salário-mínimo exerceu um papel de destaque nessa direção. Vale destacar uma ligeira perda de dinamismo entre 2013 e 2014 para os que recebem entre 1 e 1,5 salário-mínimo, em 2014, quando comparados a 2013. No entanto, o valor é reduzido e ainda não se permite falar em tendência, o que deverá ser verificado em 2015.

TABELA 9

Percentual de contribuintes e não contribuintes da previdência social por faixas de rendimentos em salários-mínimos de 2014

\begin{tabular}{lllllllll}
\hline \multirow{2}{*}{$\begin{array}{l}\text { Faixa de rendimento em } \\
\text { salários-mínimos de 2014 }\end{array}$} & \multicolumn{3}{c}{ Contribuintes } & & \multicolumn{3}{c}{ Não contribuintes } \\
\cline { 2 - 5 } \cline { 7 - 8 } & 2005 & 2013 & 2014 & & 2005 & 2013 & 2014 \\
\hline Sem declaração & 55,8 & 68,0 & 63,2 & & 44,2 & 32,0 & 36,8 \\
Até 1 & 28,6 & 29,6 & 30,9 & & 71,4 & 70,4 & 69,1 \\
Mais de 1 a 1,5 & 63,8 & 68,8 & 67,3 & & 36,2 & 31,2 & 32,7 \\
Mais de 1,5 a 3 & 69,8 & 75,4 & 75,5 & & 30,2 & 24,6 & 24,5 \\
Mais de 3 a 5 & 74,3 & 79,3 & 79,8 & & 25,7 & 20,7 & 20,2 \\
Mais de 5 a 10 & 78,6 & 83,2 & 82,3 & & 21,4 & 16,8 & 17,7 \\
Mais de 10 & 83,3 & 85,0 & 84,8 & & 16,7 & 15,0 & 15,2 \\
Total de ocupados & $\mathbf{4 8 , 9}$ & $\mathbf{6 2 , 1}$ & $\mathbf{6 2 , 3}$ & & $\mathbf{5 1 , 0}$ & $\mathbf{3 7 , 8}$ & $\mathbf{3 7 , 7}$ \\
\hline
\end{tabular}

Fonte: Pnad/IBGE (vários anos).

Elaboração Núcleo de Informações Sociais (Ninsoc/Disoc) do Ipea.

Quando o foco é a condição de inatividade, é possível perceber o quanto a informação por indivíduo apresenta uma abrangência menor que a de benefícios. A Pnad permite trabalhar com aposentados e pensionistas o que, além de limitado, pode ser errôneo ao permitir uma associação de um amparo assistencial, o Benefício de Prestação Continuada (BPC), a uma aposentadoria previdenciária. Como o foco analítico no presente estágio está centrado no indivíduo, é possível obter detalhes importantes que congregam informaçóes para todos os regimes, não sendo possível obter para as informaçóes relativas a benefícios nos diferentes regimes de previdência. A tabela 10 contém informaçôes sobre as faixas etárias dos beneficiários.

De acordo com a tabela 10, a distribuição de aposentados e pensionistas por faixas etárias revela que a maioria deles possui mais de 65 anos de idade, ou seja, o foco de cobertura da previdência são os idosos. Ainda assim, é essencial destacar que, em 2013, 40\% dos aposentados e 46\% dos pensionistas possuíam uma idade menor, o que se explica pelas seguintes razóes: 
- as idades mínimas legais de mulheres e trabalhadores rurais para a elegibilidade às aposentadorias por idade serem inferiores a 65 anos;

- as aposentadorias por tempo de contribuição não exigem idade mínima;

- as aposentadorias por invalidez e pensão por morte que não possuem exigência de idade mínima.

TABELA 10

Percentual de aposentados e pensionistas da previdência social por faixas etárias em anos de idade em relação ao total na população

\begin{tabular}{lrrrrrrrr}
\hline \multirow{2}{*}{ Faixa etária } & \multicolumn{3}{c}{ Aposentados } & & \multicolumn{3}{c}{ Pensionistas } \\
\cline { 2 - 3 } \cline { 7 - 8 } & 2005 & 2013 & 2014 & & 2005 & 2013 & 2014 \\
\hline 16 a 29 & 0,2 & 0,3 & 0,2 & & 3,8 & 2,8 & 2,4 \\
30 a 49 & 5,2 & 3,5 & 3,3 & & 18,0 & 13,4 & 12,7 \\
50 a 64 & 37,7 & 36,0 & 35,8 & & 31,0 & 29,9 & 29,9 \\
65 ou mais & 56,8 & 60,1 & 60,6 & & 47,2 & 53,9 & 55,0 \\
Total & $\mathbf{1 0 0 , 0}$ & $\mathbf{1 0 0 , 0}$ & $\mathbf{1 0 0 , 0}$ & & $\mathbf{1 0 0 , 0}$ & $\mathbf{1 0 0 , 0}$ & $\mathbf{1 0 0 , 0}$ \\
\hline
\end{tabular}

Fonte: Pnad/IBGE (vários anos).

Elaboração do Núcleo de Informações Sociais (Ninsoc/Disoc) do Ipea.

Houve uma elevação na proporção de beneficiários com mais de 65 anos entre 2005 e 2014, o que reflete o envelhecimento da população brasileira e os efeitos das reformas constitucionais de 1998 e 2003. Essas reformas tornaram a elegibilidade a benefícios mais severa, sobretudo no caso da introdução do tempo de contribuiçáo em substituição ao tempo de serviço para fins de contagem das carências para a elegibilidade. As diferenças apontadas não seriam tão perceptíveis entre 2013 e 2014, podendo ser consideradas como variaçóes na margem, à exceção dos mais idosos.

Outra informação relevante diz respeito à distribuição das aposentadorias e pensôes por faixas de renda, ou seja, em múltiplos do salário-mínimo de 2014 para os anos de 2005, 2013 e 2014, cujos resultados foram expostos na tabela 11.

Ao analisar a tabela 11, observa-se que houve uma evoluçáo positiva no valor dos benefícios entre 2005 e 2014 e essa evolução manteve-se positiva entre 2013 e 2014, não tendo perdido o seu fôlego. As faixas com rendimentos até 1,5 salários-mínimos ou sem declaração perderam participação em relação àquelas com mais de 1,5 salários-mínimos, com especial destaque para a faixa que parte desse valor até o total de três salários mínimos. Essa evolução deve-se, em parte, ao crescimento do poder de compra do salário-mínimo, mas, também à melhoria dos indicadores econômicos ao longo dos anos que tiveram efeitos relevantes sobre a ocupação e também na renda dos aposentados e pensionistas. As políticas de 
defesa do poder de compra de aposentadorias e pensóes, com especial destaque para o piso previdenciário, que equivale a um salário-mínimo no Brasil, é de especial relevância para compreender a evolução dos indicadores da tabela 11 .

\section{TABELA 11}

Percentual de aposentados e pensionistas da previdência social por faixas de rendimentos em salários-mínimos de 2014 em relação ao total

\begin{tabular}{lccccccc}
\hline \multirow{2}{*}{$\begin{array}{l}\text { Faixa de rendimento em } \\
\text { salários-mínimos de 2014 }\end{array}$} & \multicolumn{3}{c}{ Aposentados } & & \multicolumn{3}{c}{ Pensionistas } \\
\cline { 2 - 4 } \cline { 6 - 8 } Sem declaração & 2005 & 2013 & 2014 & & 2005 & 2013 & 2014 \\
Até 1 & 1,2 & 2,8 & 2,6 & & 0,9 & 2,4 & 1,9 \\
Mais de 1 a 1,5 & 46,6 & 40,7 & 40,1 & & 40,3 & 27,6 & 28,3 \\
Mais de 1,5 a 3 & 16,0 & 11,9 & 11,0 & & 25,2 & 11,4 & 10,4 \\
Mais de 3 a 5 & 18,0 & 25,9 & 26,4 & & 20,8 & 42,6 & 43,6 \\
Mais de 5 a 10 & 9,1 & 9,2 & 3,5 & & 7,1 & 8,4 & 2,0 \\
Mais de 10 & 5,7 & 6,3 & 9,8 & & 4,2 & 5,6 & 9,2 \\
Total & 3,4 & 3,3 & 6,6 & & 1,6 & 2,1 & 4,8 \\
\hline
\end{tabular}

Fonte: Pnad/IBGE (vários anos).

Elaboração do Núcleo de Informações Sociais do (Ninsoc/Disoc) do Ipea.

Em suma, com base no perfil de aposentadorias, pensões e contribuintes para a previdência pública, é possível relatar que houve uma melhoria generalizada nos indicadores. $\mathrm{O}$ total de contribuintes elevou-se graças à melhoria nas condiçóes econômicas, políticas de estímulo à inserção nessa condição e a esforços de fiscalização e de concessão de crédito (com destaque para o crédito consignado) para quem se encontra na condição de segurado. A valorização do poder de compra do salário-mínimo e a evolução positiva do PIB devem ser destacadas nesse contexto, deixando entrever a importância da condição econômica sobre a saúde financeira da previdência. Esses efeitos positivos refletem-se entre todos os contribuintes e beneficiários com a elevação do poder de compra dos proventos.

\section{TEMAS EM DESTAQUE}

As questôes analisadas na seção de Temas em destaque são: pensôes por morte e mudanças na fórmula de cálculo do benefício da aposentadoria por tempo de contribuição em função das mudanças na aplicação do fator previdenciário com a introdução da regra 85/95 progressiva para 90/100. As alteraçóes nas regras de pensão por morte decorrentes da MP no 664 e sua conversão na Lei nº 13.135/2015 já foram discutidas na seção Fatos relevantes. Aqui haverá análise das alterações nas regras de pensão no sentido de buscar a racionalidade dessas mudanças, bem como uma breve comparação internacional a respeito. Também será discutida a questão da pensão à luz das alteraçóes no mercado de trabalho, mais especificamente, 
o aumento da taxa de participação da mulher. Por fim, serão discutidas com maior profundidade as implicaçôes da alteração na aplicação do fator previdenciário.

\subsection{Pensões por morte - comparação internacional}

Pode-se afirmar que as regras prevalecentes para concessão de pensão por morte no Brasil, antes da MP no ${ }^{-664}$, eram desalinhadas com os padróes internacionais, o que resulta em um elevado nível de despesas em relação a estrutura demográfica do país. Nesse sentido, as propostas que foram encaminhadas ao Congresso Nacional, pela MP no 664, realmente tinham como finalidade correçóes de algumas distorçóes presentes nas regras brasileiras e, dessa forma, colaborar com a melhoria da sustentabilidade fiscal do RGPS, sem prejuízos ao sistema de proteçáo social. Outro ponto importante é que existe a necessidade de reavaliar as regras previdenciárias em função das transformaçóes econômicas e sociais do país, em especial, ao processo demográfico de envelhecimento populacional e também à crescente participação das mulheres no mercado de trabalho.

Em relação ao cotejamento com os padrôes internacionais, conforme mostrado por Ansiliero, Costanzi e Pereira (2014), ${ }^{7}$ em um estudo com 132 naçóes: i) 78\% dos países exigiam então algum tipo de carência; ii) $81,8 \%$ dos países colocavam condicionantes para uma taxa de reposição de $100 \%$; e, iii) $76,5 \%$ impunham restriçóes para cônjuges e/ou equiparados (como, por exemplo, a exigência de idade mínima para o cônjuge ou tempo mínimo de união). No Brasil, antes da MP nº 664, nenhuma dessas exigências estava prevista no ordenamento jurídico do RGPS. As regras anteriores à $\mathrm{MP}$ no 664 permitiam que mais pessoas fossem elegíveis ao benefício e que o recebessem por mais tempo (Rocha e Abi-Ramia, 2008). ${ }^{8}$ Contudo, como discutido anteriormente, as distorçôes foram apenas parcialmente corrigidas pela Lei no ${ }^{\circ} 13.135 / 2015$.

Importante salientar que a falta de aderência aos majoritários padróes de carência, tempo mínimo de casamento e condicionalidades para concessão para cônjuges não se trata de uma mera questão de seguir padróes sem racionalidade, mas de regras necessárias para evitar distorçóes no sistema de seguridade social. A título de exemplo, em relação às distorçóes, não parece adequado garantir pagar benefícios vitalícios para cônjuges jovens e sem filhos que têm adequado nível de renda e plena capacidade laboral, pois a função precípua da previdência deveria ser garantir renda para aquelas famílias que, por algum motivo, perderam a capacidade de autossustento por incapacidade laboral ou morte do instituidor ou outra circunstância. Também é inadequado não ter restrição legal para o pagamento de pensão para dependente que cometeu crime doloso que resultou na morte do instituidor.

7. Ver Ansiliero, Costanzi, Pereira (2014).

8. Ver Rocha, Caetano (2008). 
Essa discrepância das regras com o padrão internacional refletia-se no nível de despesa com pensôes por morte em porcentagem (\%) do PIB em relação à estrutura demográfica. Nota-se que o Brasil é um ponto "fora da curva" que relaciona a estrutura demográfica com o gasto com essa espécie de benefício em \% do PIB (Costanzi e Ansiliero, 2015). ${ }^{9}$ Como pode ser observado pelo gráfico 1, os dados indicam que o percentual do PIB brasileiro comprometido com o pagamento de pensão por morte supera em muito aquele observado para países com razão de dependência assemelhada ou estrutura demográfica similar. Um nível de gasto em \% do PIB similar é observado para países com estrutura demográfica muito mais envelhecida que a brasileira. O destoante nível de gasto não resulta do perfil demográfico nacional, para o qual se adotou como proxy a razão de dependência de idosos, mas está relacionado com as regras de concessão prevalecentes antes da MP no 664.

\section{GRÁFICO 1}

Despesa com o pagamento de pensão por morte como proporção do PIB versus razão de dependência dos idosos para 43 países

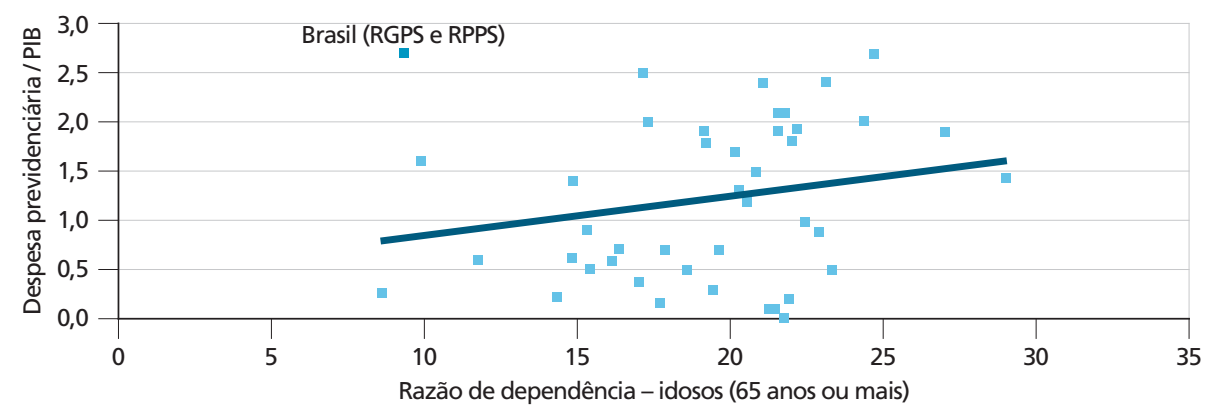

Fonte: Costanzi e Ansiliero (2015), com base em dados da Associação Internacional de Seguridade Social - AISS (2013 e 2014), Organização para a Cooperação e Desenvolvimento Econômico (OCDE), Gabinete de Estatísticas da União Europeia (Eurostat) e Ministério do Trabalho e Previdência Social.

As despesas com pensão por morte, apenas no RGPS, cresceram de $\mathrm{R}$ \$ 44,4 bilhôes, em 2002, para o patamar de R \$ 94,8 bilhôes, em 2014, em valores a preços corrigidos pelo INPC médio de 2014, que representou um incremento relativo acumulado de $113,5 \%$ e médio anual de $6,5 \%$ ao ano (a.a.) (ver gráfico 2 ). $\mathrm{O}$ crescimento médio anual da despesa com pensôes urbanas e rurais foram de, respectivamente, $6,3 \%$ a.a. e 7,3\% a.a. em valores reais, ou seja, já eliminado o efeito da inflação. Em termos de despesa em \% do PIB, a mesma cresceu de 1,4\%, em 2002, para 1,7\%, em 2014, apenas com as despesas do RGPS, ou seja, sem considerar aquelas dos regimes próprios de previdência dos servidores públicos. 
GRÁFICO 2

Despesa com o pagamento de pensão por morte no RGPS Brasil - de 2002 a 2014 a preços de INPC médio de 2014

(Em R\$ bilhões)

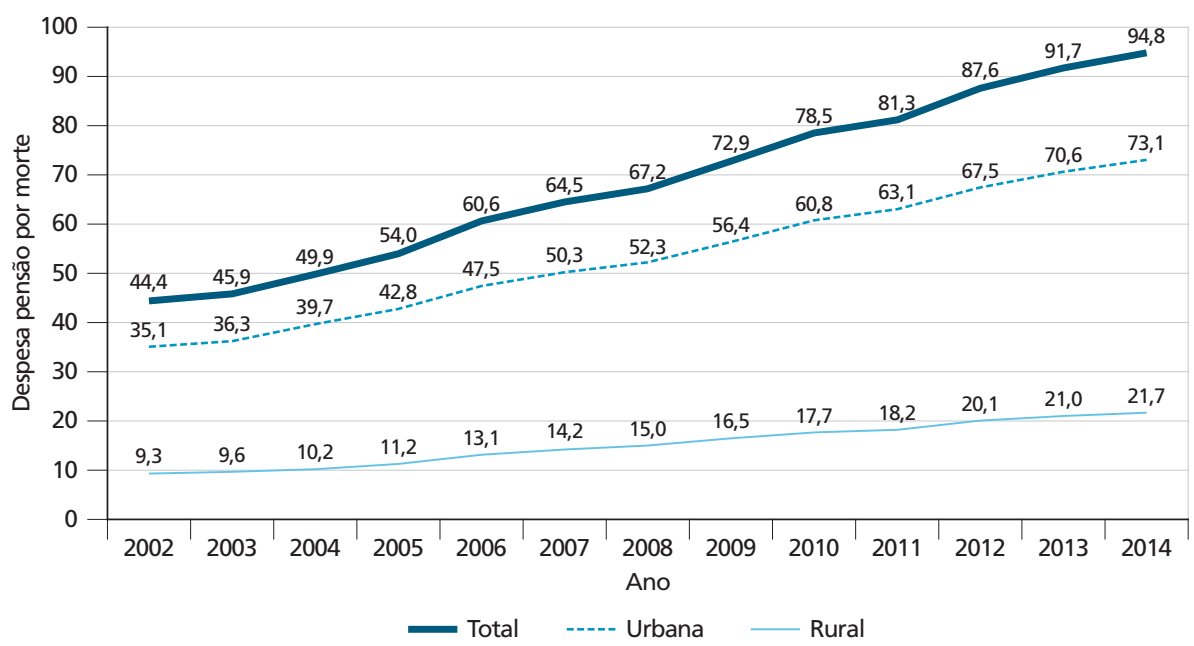

Fonte: Ministério do Trabalho e Previdência Social.

Elaboração dos autores.

\section{GRÁFICO 3}

Estoque de benefícios de pensão por morte no RGPS Brasil - em dezembro de cada ano de 1995 a 2014

(Em R\$ mil)

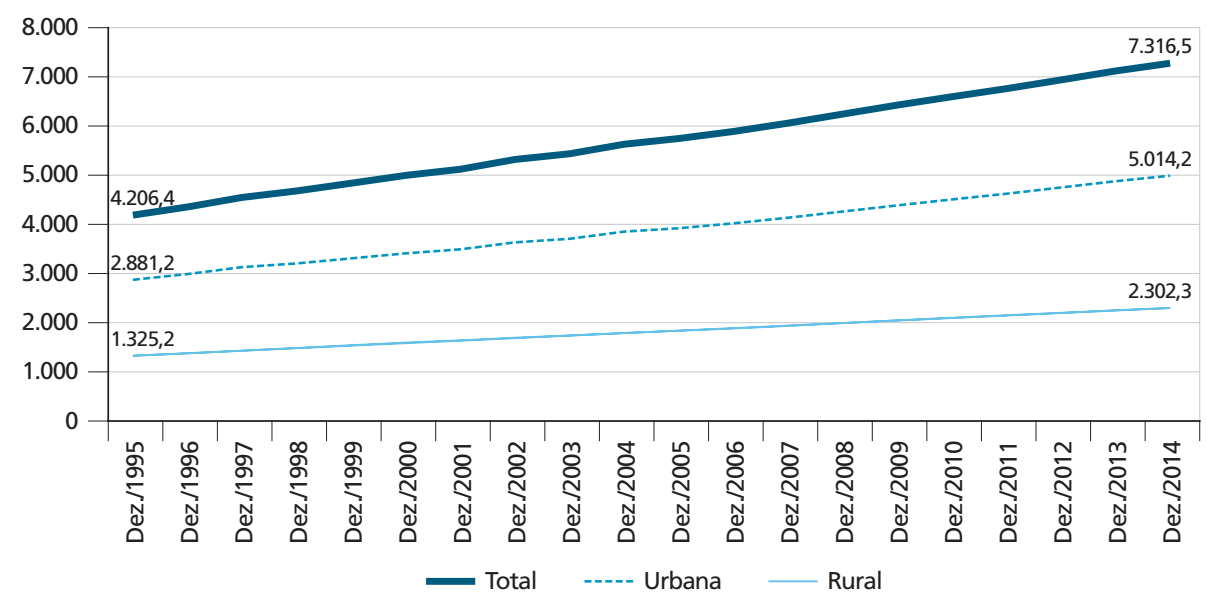

Fonte: Ministério do Trabalho e Previdência Social.

Elaboração dos autores.

Esse incremento da despesa com as pensões no âmbito do RGPS reflete tanto o aumento real do valor do benefício, em especial, por conta da valorização 
real do salário-mínimo, como também pelo crescimento vegetativo do estoque de benefícios. O total de pensóes por morte emitidas, em dezembro de cada ano, cresceu de cerca de 4,2 milhóes, em dezembro de 1995, para 7,3 milhóes de benefícios em dezembro de 2014 (ver gráfico 3).

\subsection{Pensões por morte e mudanças no mercado de trabalho}

Outro ponto importante na discussão sobre as pensões por morte é que seu papel de proteção social precisa ser reavaliado frente às transformaçóes que ocorreram e continuam a ocorrer no mundo laboral. Em decorrência da crescente participação das mulheres no mercado formal de trabalho tem crescido de forma significativa o percentual de pensionistas que acumulam benefícios de pensão e aposentadoria (Costanzi, 2015; Costanzi e Ansiliero, 2015). ${ }^{10}$

Em 1992, apenas 9,9\% dos pensionistas acumulavam pensão com aposentadoria, percentual que se elevou para 31,6\% em 2013 (sem considerar o Norte Rural do país, mas sim a área rural de Tocantins) e a tendência é que se eleve ainda mais no futuro. Considerando-se apenas as mulheres, que são a maioria entre os pensionistas, a proporção daqueles que acumulavam aposentadoria e pensão passou de 9,9\%, em 1992, para 31\% em 2013 (Tabela 12). ${ }^{11}$

Considerando-se aqueles pensionistas que acumulavam aposentadoria ou estavam ocupados com contribuição, o percentual de pensionistas com dupla proteção elevou-se de 21,3\%, em 1992, para 39,7\%, em 2013 (sempre na série histórica harmonizada para as áreas rurais). Fazendo o cotejamento apenas para as mulheres, o percentual cresceu de 20,6\%, em 1992, para 38,6\%, em 2013. Ademais, em 2013, havia cerca de 347 mil pessoas que acumulavam pensão, aposentadoria e renda do trabalho, sendo que, em 1992, eram apenas cerca de 55 mil.

Em 2013, praticamente a metade dos pensionistas tinha pelo menos outra fonte de rendimento. Do ponto de vista da proteção social, parece pouco justificável garantir renda de forma incondicional para quem já tem outra fonte de rendimento. Há necessidade de reavaliar o procedimento atual de tratar o cônjuge do instituidor como dependente de forma presumida no cenário atual de incremento da participação da mulher no mercado de trabalho e garantir renda para quem já tem outra fonte de rendimento. Por um lado, deve-se lembrar que a pensão por morte consiste em benefício contributivo, apenas devido a dependentes de segurados da previdência social. Por outro, deve-se ter claro que o financiamento por fonte diferenciada, para aposentadoria e pensão, não necessariamente é suficiente para que atuarialmente haja um equilíbrio entre cotizaçóes e benefícios.

10. Ver Costanzi (2015) e Costanzi e Ansiliero (2015).

11. Comparação entre 1992 e 2013, sem área rural do Norte. 


\section{TABELA 12}

Situação dos pensionistas (acumulação de benefícios, condição de atividade, condição de ocupação e fontes de rendimento), segundo gênero, 1992 e 2013 - Brasil

\begin{tabular}{|c|c|c|c|}
\hline \multicolumn{4}{|l|}{ Brasil - homens e mulheres } \\
\hline Situação do pensionista & 1992 & $\begin{array}{l}\text { 2013, sem norte } \\
\text { rural - série }\end{array}$ & $\begin{array}{l}\text { 2013, com norte } \\
\text { rural }\end{array}$ \\
\hline I - Total de pensionistas (II + III) & 3.339 .086 & 6.903 .831 & 6.954 .563 \\
\hline II - Pensionistas que acumulam aposentadoria & 330.046 & 2.179 .566 & 2.196 .235 \\
\hline II.1 Aposentadoria e não ocupados & 1.725 & 1.618 & 1.618 \\
\hline II.2 Aposentadoria e ocupados com contribuição & 12.943 & 37.215 & 37.459 \\
\hline II.3 Aposentadoria e ocupados sem contribuição & 41.885 & 304.488 & 309.937 \\
\hline II. 4 Aposentadoria e não economicamente ativos & 273.493 & 1.836 .245 & 1.847.221 \\
\hline III - Pensionistas que não acumulam aposentadoria & 3.009 .040 & 4.724 .265 & 4.758 .328 \\
\hline III.1 Sem aposentadoria e não ocupados & 66.365 & 79.119 & 79.362 \\
\hline III.2 Sem aposentadoria e ocupados com contribuição & 382.386 & 562.952 & 565.357 \\
\hline III.3 Sem aposentadoria e ocupados sem contribuição & 638.821 & 628.667 & 639.690 \\
\hline III. 4 Sem aposentadoria e não economicamente ativos & 1.921 .251 & 3.453 .527 & 3.473 .919 \\
\hline III. 5 Sem declaração & 217 & - & - \\
\hline Percentual que acumula aposentadoria (II/I em \% total) & $9,9 \%$ & $31,6 \%$ & $31,6 \%$ \\
\hline Percentual que tem outra fonte formal de renda em $\%$ total & $21,3 \%$ & $39,7 \%$ & $39,7 \%$ \\
\hline Percentual que tem outra fonte de renda em $\%$ do total & $40,5 \%$ & $48,8 \%$ & $48,9 \%$ \\
\hline I - Total de pensionistas (II + III) & 3.118 .255 & 6.007 .517 & 6.044 .737 \\
\hline II - Pensionistas que acumulam aposentadoria & 307.690 & 1.863 .030 & 1.875 .895 \\
\hline II.1 Aposentadoria e não ocupados & 1.470 & 1.618 & 1.618 \\
\hline II.2 Aposentadoria e ocupados com contribuição & 10.819 & 28.100 & 28.100 \\
\hline II.3 Aposentadoria e ocupados sem contribuição & 37.366 & 244.471 & 248.973 \\
\hline II. 4 Aposentadoria e não economicamente ativos & 258.035 & 1.588 .841 & 1.597 .204 \\
\hline III - Pensionistas que não acumulam aposentadoria & 2.810 .565 & 4.144 .487 & 4.168 .842 \\
\hline III.1 Sem aposentadoria e não ocupados & 57.814 & 64.627 & 64.870 \\
\hline III.2 Sem aposentadoria e ocupados com contribuição & 334.783 & 454.714 & 455.687 \\
\hline III.3 Sem aposentadoria e ocupados sem contribuição & 586.169 & 515.771 & 522.898 \\
\hline III. 4 Sem aposentadoria e não economicamente ativos & 1.831 .582 & 3.109 .375 & 3.125 .387 \\
\hline III. 5 Sem declaração & 217 & - & - \\
\hline Percentual que acumula aposentadoria (II// em \% total) & 9,9 & 31,0 & 31,0 \\
\hline Percentual que tem outra fonte formal de renda em $\%$ total & 20,6 & 38,6 & 38,6 \\
\hline Percentual que tem outra fonte de renda em $\%$ do total & 39,4 & 47,2 & 47,2 \\
\hline
\end{tabular}

Fonte: Costanzi (2015) e Costanzi e Ansiliero (2015).

Elaborado com base nos microdados da Pnad/IBGE (1992; 2013). ${ }^{12}$

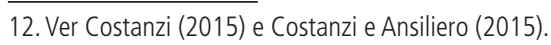




\subsection{Duração das pensões por morte e impacto fiscal da MP no 664/2014 e da Lei no 13.135/2015}

Além das questôes anteriores, cabe analisar de forma mais individualizada a questão da duração do benefício. A regra sancionada, conforme mostrado anteriormente, estabeleceu que a duração será variável, conforme a idade do cônjuge.

Apesar dessas alteraçóes, a maior parte das pensões para cônjuge deve continuar a ser vitalícia, a julgar da análise das concessóes realizadas em 2014. De um total de cerca de 355 mil pensóes por morte concedidas para cônjuges em 2014 no RGPS, cerca de 308 mil eram de dependentes com 44 anos ou mais de idade e, portanto, $86,7 \%$ continuariam a ter direito à pensão vitalícia. Ainda tendo como base as concessôes de 2014, poder-se-ia estimar a seguinte distribuição para os benefícios não vitalícios: i) 2,9\% das concessóes para cônjuge teriam duração de vinte anos; ii) $7,4 \%$ teriam duração de quinze anos; iii) 1,3\% teriam duração de dez anos; iv) $1,4 \%$ teriam duração de seis anos; $v$ ) apenas $0,3 \%$ teriam duração de três anos. Claro, contudo, que essas simulaçóes foram feitas com base nas concessōes realizadas em 2014 e tendem a mudar, inclusive, porque essas idades tendem a subir ao longo do tempo de acordo com o incremento da expectativa de vida ao nascer.

Com o abandono da expectativa de sobrevida, conseguiu-se evitar que a atualização pudesse ocorrer de forma anual. Pela regra introduzida pelo Congresso, o incremento das idades pode ocorrer, no mínimo, de três em três anos. Entretanto, ao vincular a alteração da idade ao incremento da expectativa de vida ao nascer, introduz-se um fator de alteração que tende a crescer mais rápido que a sobrevida, pois esse indicador tende a ter um ritmo de incremento absoluto superior ao da sobrevida para idades bem acima de zero.

De qualquer forma, a alteração justifica-se pelo fato de que não faz sentido pagar pensáo por morte vitalícia para pessoas com plena capacidade laboral, às vezes até com renda do trabalho, em especial, se forem sem filhos e muito jovens. Cabe destacar que havendo filhos menores de 21 anos haverá pagamento de pensão. O período de pagamento pode ser visto como um intervalo de tempo em que se daria a possibilidade do cônjuge/viúvo(a), caso não trabalhasse, buscar inserção no mercado de trabalho. Entretanto, na proposta original da MP nº 664, o benefício tinha duração de quinze anos para uma pessoa de 43 anos, que resultaria na cessação do benefício com idade de 58 anos. Na proposta alterada pelo Congresso, uma pessoa de 43 anos terá sua pensão cessada aos 63 anos, ou seja, com idade relativamente avançada, que tenderá a crescer ao longo do tempo.

Do ponto de vista fiscal, essa medida terá algum efeito apenas a partir de 2018; e o fato que a maioria ainda continuaria com o benefício vitalício, faz com que seu impacto seja mais reduzido. Claro, contudo, que a medida deverá reduzir a duração média das pensóes por morte e atuará no sentido de eliminar 
pensôes de longa duração, que eram exatamente aquelas que vinham apresentando a maior taxa de crescimento.

A duração média das pensões por morte cessadas no âmbito do RGPS teve tendência de alta no período entre 1995 e 2013, tendo crescido de treze para dezesseis anos (gráfico 4). Provavelmente, um dos fatores que ajudam a explicar este incremento é o próprio incremento da expectativa de sobrevida no referido período. Obviamente, a realização de casamentos de pessoas com idade bem avançada para cônjuges bem mais jovens também é um fator que tende a elevar a duração média no cenário anterior à $\mathrm{MP} \mathrm{n}^{\circ} \mathbf{6 6 4}$, que garantia o benefício vitalício independentemente da idade do viúvo(a), se tinha ou não renda e da sua situação em termos de capacidade laboral. Apenas a condicionalidade em relação à idade foi alterada, sendo que foi mantida a presunção da dependência econômica do(a) viúvo(a), que não precisa ser provada.

GRÁFICO 4

Duração média das pensões por morte cessadas no RGPS (Brasil 1995-2013) (Em anos)

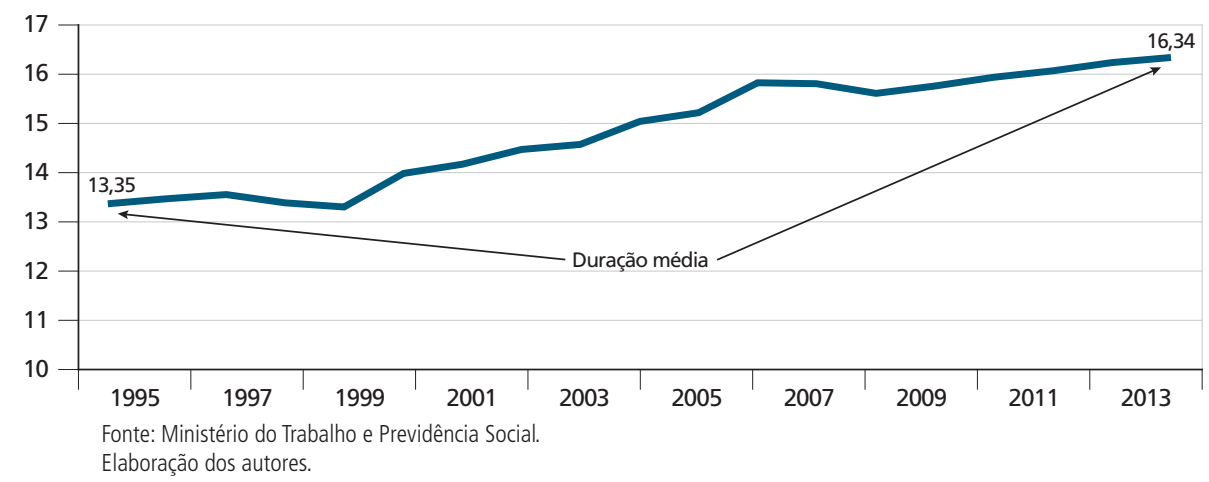

A análise da duração das pensôes cessadas mostra que o maior incremento ocorreu exatamente para aquelas com maior duração: na comparação daquelas cessadas em $1995 \mathrm{com}$ as de 2013, nota-se que as maiores taxas de incremento foram para aquelas com duração de 25 anos ou mais, com destaque para aquelas com duraçáo de trinta a 34 anos e 35 a 39 anos, cujos incrementos foram de, respectivamente, $620 \%$ e $690 \%$ (ver tabela 13 ). Com as alteraçóes sancionadas pela Lei no $13.135 / 2015$, deve haver um incremento menor das pensóes com duração mais elevada, o que deve criar, ceteris paribus, alguma tendência de queda na duração média, mas limitada, tendo em vista que a maioria deverá continuar a ser vitalícia. Cabe enfatizar, também, que as novas regras aplicam-se apenas às novas concessões de pensóes e não ao estoque de benefício (pensóes já concedidas) por respeito a direitos adquiridos. Por essa razão, o impacto tende a ser limitado em um primeiro momento, já que afeta apenas as novas concessões e cresce de 
maneira expressiva ao longo do tempo, à medida que o estoque de benefícios afetados vai aumentando.

TABELA 13

Quantidade de pensões por mortes cessadas por faixa de duração RGPS Brasil 1995 a 2013

\begin{tabular}{lccc}
\hline Tempo de duração & 1995 & 2013 & Variação 2013/1995 \\
\hline Até 4 anos & 18.580 & 47.310 & $255 \%$ \\
De 5 a 9 anos & 21.202 & 46.315 & $218 \%$ \\
De 10 a 14 anos & 20.489 & 41.229 & $201 \%$ \\
De 15 a 19 anos & 16.872 & 36.678 & $217 \%$ \\
De 20 a 24 anos & 9.668 & 26.589 & $275 \%$ \\
De 25 a 29 anos & 4.295 & 22.441 & $522 \%$ \\
De 30 a 34 anos & 2.806 & 17.387 & $620 \%$ \\
De 35 a 39 anos & 1.675 & 11.554 & $690 \%$ \\
Acima de 40 anos & 2.389 & 9.446 & $395 \%$ \\
Ignorada & 3.033 & 585 & $19 \%$ \\
Total & 101.009 & 259.534 & $257 \%$ \\
\hline
\end{tabular}

Fonte: Ministério do Trabalho e Previdência Social.

Elaboração dos autores.

\subsection{Fórmula de cálculo do benefício da aposentadoria}

A alteração do fator previdenciário, proposta pelo Congresso Nacional, de não aplicação quando a soma de idade com o tempo de contribuição, considerada na data de requerimento da aposentadoria, fosse de 85 para mulheres, com pelo menos trinta anos de contribuiçáo, e 95 para homens, com pelo menos 35 anos de contribuição, não trouxe uma melhora da situação fiscal do RGPS a médio e longo prazos, mas, ao contrário, acarretará em piora das contas e da sustentabilidade do RGPS, que já serão fortemente afetadas pela transição demográfica, mais especificamente pelo rápido processo de envelhecimento populacional.

A emenda aprovada pelo Congresso Nacional, além do estabelecimento da regra 85/95 fixa, ou seja, sem progressão com o tempo, de forma a acompanhar o incremento da expectativa de sobrevida, também tinha outros elementos: i) não aplicação do fator previdenciário quando o segurado fosse pessoa com deficiência; ii) garantia de congelamento da tábua de expectativa de sobrevida no momento de cumprimento dos requisitos, ou seja, ficava garantido ao segurado que optasse por permanecer em atividade, se mais vantajoso, o direito ao cálculo do salário de benefício com base na expectativa de sobrevida presente na tábua de mortalidade vigente na data de cumprimento dos requisitos necessários à aposentadoria por tempo de contribuição, considerando-se sua idade e seu tempo de contribuição no 
momento de requerimento do benefício; iii) para efeito da aplicação do fator 85/95, o tempo de contribuição do professor e da professora da educação infantil, do ensino fundamental e médio seria acrescido de cinco anos. Em relação à não aplicação do fator previdenciário para segurado com deficiência, essa proposta era sem sentido, tendo em vista que esse tratamento diferenciado já estava em vigor pelo Artigo 9o da Lei Complementar nํㅜ 142, de 8 de maio 2013, que regulamentou a previsão constitucional de critérios diferenciados de aposentadoria para pessoas com deficiência no âmbito do RGPS. ${ }^{13}$

Todo o conteúdo da emenda foi vetado pelo Poder Executivo, sob o adequado argumento de que a alteração realizada pelos dispositivos não acompanhava a transição demográfica brasileira e trazia riscos ao equilíbrio financeiro e atuarial da previdência social, contrariado esse referido preceito constitucional estabelecido no Artigo 201. Contudo, na própria justificativa do veto, o governo expóe que editaria medida provisória para enfrentar a questão de modo a preservar a sustentabilidade da previdência social. Efetivamente, de forma simultânea ao veto, o governo promulgou a Medida Provisória n⿳o 676, de 17 de junho de 2015, que propôs ao segurado que preenchesse o requisito para a aposentadoria por tempo de contribuição poder optar pela não incidência do fator previdenciário, quando o total resultante da soma de sua idade e de seu tempo de contribuiçáo, na data de requerimento da aposentadoria, for: i) igual ou superior a 95 pontos, se homem, observando o tempo mínimo de contribuição de 35 anos; b) igual ou superior a 85 pontos, se mulher, observando o tempo mínimo de contribuição de trinta anos.

$\mathrm{Na}$ realidade, a única diferença da MP no 676/2015, em relação ao que foi aprovado pelo Congresso durante a tramitação da MP no 664/2014, é que a regra $85 / 95$ não seria fixa ao longo do tempo, apenas adicionando progressão para $90 / 100$ até 2022, mantendo-se fixo a partir de 2022. A progressão proposta pelo Poder Executivo é mostrada no quadro 3. Para efeito da aplicação da regra 85/95 progressiva para professores, há previsão de acréscimo de cinco pontos, para compensar que o tempo de contribuição exigido para esses profissionais é reduzida também em cinco anos, por determinação constitucional.

Durante a tramitação no Congresso Nacional, em relação à regra 85/95, houve apenas a alteração da progressão, que ficou ainda mais lenta do que aquela proposta inicialmente pelo Poder Executivo. Enquanto a proposta do Executivo era atingir 90/100 em $1^{\circ}$ de janeiro de 2022, na alteração feita no Legislativo e posteriormente sancionada pela Lei no 13.183 , de 4 de novembro de 2015 , a regra 90/100 será atingida apenas em 31 de dezembro de 2026, ou seja, em 2027. O Congresso também chegou a aprovar a desaposentação, mas a medida foi vetada pelo Poder Executivo.

13. Ainda não foi aprovada regulamentação similar nos regimes próprios dos servidores públicos. 
QUADRO 3

Progressão da soma que permite não aplicação do fator previdenciário proposto pela MP no 676/2015 e na conversão pela Lei no 13.183/2015

\begin{tabular}{|c|c|c|c|}
\hline \multicolumn{2}{|c|}{ Período de vigência da regra } & \multicolumn{2}{|c|}{$\begin{array}{l}\text { Soma de idade mais tempo de contribuição que } \\
\text { resulta na não aplicação do fator previdenciário }\end{array}$} \\
\hline \multicolumn{2}{|c|}{17 de junho de 2015 a 31 de dezembro de 2016} & \multicolumn{2}{|c|}{85 para mulheres e 95 para homens } \\
\hline \multicolumn{2}{|c|}{ 1ํ de janeiro de 2017 a 31 de dezembro de 2018} & \multicolumn{2}{|c|}{86 para mulheres e 96 para homens } \\
\hline \multicolumn{2}{|c|}{ 1 de janeiro de 2019 a 31de dezembro de 2019} & \multicolumn{2}{|c|}{87 para mulheres e 97 para homens } \\
\hline \multicolumn{2}{|c|}{ 1ํ de janeiro de 2020 a 31 de dezembro de 2020} & \multicolumn{2}{|c|}{88 para mulheres e 98 para homens } \\
\hline \multicolumn{2}{|c|}{ 1ํ de janeiro de 2021 a 31 de dezembro de 2021} & \multicolumn{2}{|c|}{89 para mulheres e 99 para homens } \\
\hline \multicolumn{2}{|l|}{ A partir de 1ㅇ de janeiro de 2022} & \multicolumn{2}{|c|}{90 para mulheres e 100 para homens } \\
\hline $\begin{array}{l}\text { Soma de idade mais tempo de } \\
\text { contribuição que resulta na não } \\
\text { aplicação do fator previdenciário }\end{array}$ & \multicolumn{2}{|c|}{$\begin{array}{l}\text { Progressão proposta pela } \\
\qquad \text { MP no } 076 / 2015\end{array}$} & $\begin{array}{l}\text { Progressão sancionada pela } \\
\text { Lei no } 13.183 / 2015\end{array}$ \\
\hline 85 para mulheres e 95 para homens & \multicolumn{2}{|c|}{$\begin{array}{l}17 \text { de junho de } 2015 \\
\text { a } 31 \text { de dezembro de } 2016\end{array}$} & $\begin{array}{l}17 \text { de junho de } 2015 \\
\text { a } 30 \text { de dezembro de } 2018\end{array}$ \\
\hline 86 para mulheres e 96 para homens & \multicolumn{2}{|c|}{ 1o de janeiro de 2017} & 31 de dezembro de 2018 \\
\hline 87 para mulheres e 97 para homens & \multicolumn{2}{|c|}{ 1o de janeiro de 2019} & 31 de dezembro de 2020 \\
\hline 88 para mulheres e 98 para homens & \multicolumn{2}{|c|}{ 1ํ de janeiro de 2020} & 31 de dezembro de 2022 \\
\hline 89 para mulheres e 99 para homens & \multicolumn{2}{|c|}{ 1o de janeiro de 2021} & 31 de dezembro de 2024 \\
\hline 90 para mulheres e 100 para homens & \multicolumn{2}{|c|}{ 10 de janeiro de 2022} & 31 de dezembro de 2026 \\
\hline
\end{tabular}

Fonte: Medida Provisória no 676/2015 e Lei no 13.183/2015.

Portanto, embora o governo tenha vetado a regra 85/95, com o argumento de que preservaria a sustentabilidade da previdência social, a MP no 676 e sua posterior conversão na Lei no ${ }^{\circ} 13.183 / 2015$ propóe uma fórmula 85/95 progressiva até $90 / 100$ que, embora tenha um impacto menor que a 85/95 fixa, também aumentará de forma expressiva a despesa do RGPS, em especial, a médio e longo prazos.

Algumas críticas podem ser feitas em relação ao fator com fórmula progressiva. Em primeiro lugar, não existe nenhuma justificativa técnica ou atuarial para não aplicação do fator a partir de uma determinada soma de idade mais tempo de contribuição, a não ser o desejo político de conceder aposentadorias com maior valor. Tampouco há qualquer explicação racional em relação à progressão que foi proposta. Ademais, a lei sancionada mantém a progressão fixa em 90/100, a partir de 2027, na prática, algo incoerente com o esperado aumento da expectativa de sobrevida. Portanto, embora o governo tenha vetado a regra 85/95, a proposta feita também terá efeitos negativos sobre a sustentabilidade do RGPS, pois tenderá a aumentar a despesa do RGPS, sendo que esse aumento terá caráter regressivo do ponto de vista distributivo como será discutido posteriormente.

Claro, contudo, que o fator previdenciário, desde sua criação, sempre foi um mecanismo polêmico de estímulo à postergação da aposentadoria, pois teve efeito aparentemente limitado no incremento da idade de aposentadoria, 
gerando descontos expressivos no valor dos benefícios. Na realidade, o fator previdenciário foi a alternativa encontrada perante o insucesso em estabelecer uma idade mínima para a aposentadoria por tempo de contribuição. Portanto, mesmo que fosse compreensível a busca de uma alternativa ao fator, em especial, uma que evitasse aposentadorias precoces, levando a um equilíbrio com aposentadorias com idades e valores mais elevados, a MP no 676 e sua posterior conversão na Lei no ${ }^{\circ} 13.183 / 2015$ não foi uma solução estrutural para os problemas da previdência, como é um paliativo que pode comprometer de forma regressiva a sustentabilidade do RGPS a médio e longo prazos.

Para se aprofundar sobre essa discussão, é fundamental a análise de alguns dados a respeito da aposentadoria por tempo de contribuição e do fator previdenciário. Um primeiro aspecto é que a aposentadoria por tempo de contribuição, que tem como regra a concessáo de aposentadoria para homens com 35 anos e mulheres com trinta anos de contribuição, sem qualquer restrição direta sobre a idade, ou seja, com ausência de uma idade mínima, tem gerado aposentadorias precoces para pessoas com plena capacidade laboral, que muitas vezes continuam a trabalhar depois da aposentadoria, o que certamente é uma distorção para um sistema de proteção social. A aposentadoria por tempo de contribuiçẫo, em algum grau, deixou de ser um mecanismo de substituição de renda para ser complementação de renda para pessoas com renda muito superior a qualquer linha de pobreza que possa ser utilizada e acima da base de rendimentos.

Um conjunto de dados que comprova o diagnóstico de aposentadorias precoces é mostrado na tabela 14 e no gráfico 5: quase metade $(48,4 \%)$ das aposentadorias por tempo de contribuição (ATC), em 2014, foi concedida para segurados com idade de até 54 anos, sendo mais de dois terços $(67,9 \%)$ do total, no caso das mulheres, e mais de um terço, no caso dos homens (39\%). Caso seja ampliada a faixa etária para 59 anos, se chega a $83 \%$ das ATCs concedidas, sendo 76,9\% para homens e $95,6 \%$, no caso das mulheres, e, portanto, a grande maioria das ATCs concedidas, em 2014, era para pessoas que não eram idosas no momento de concessão da aposentadoria. A idade média na data da aposentadoria, para a ATC, foi de 54 anos, sendo 55 anos para homens e apenas 52 anos para mulheres. Um homem com 55 anos tem, atualmente, uma expectativa de sobrevida de 23,8 anos; uma mulher de 52 anos espera-se que viva mais 30,4 anos, sempre com dados do IBGE. ${ }^{14}$ Chama atençáo que no caso das mulheres, a sobrevida é mais que o tempo de contribuição exigido. Ademais, a expectativa é que esses valores cresçam ainda mais no futuro.

14. Tanto para homens quanto para mulheres, considerou-se a tabela de expectativa de vida e sobrevida divulgada pelo IBGE em dezembro de 2015. 
Em função da combinação de aposentadorias precoces e fator previdenciário, acaba havendo, em geral, descontos expressivos no valor da aposentadoria. A título de exemplo, usando a tabela prevalecente desde dezembro de 2014 e na maior parte de 2015, um homem com 55 anos de idade e 35 anos de contribuição, teria um fator previdenciário de 0,7 , que representa um desconto de $30 \%$ no valor do benefício em relação ao que prevaleceria se fosse considerada apenas a média dos $80 \%$ maiores salários de contribuição desde julho de 1994 . No caso de uma mulher, com 52 anos de idade e trinta anos de contribuição, o fator previdenciário seria de 0,629 , que representa uma redução do valor do benefício de cerca de $37,1 \%$. Uma explicação para esse comportamento, dado a magnitude da redução, é que muitos segurados preferem se aposentar táo logo completem 30 ou 35 anos de contribuição, pois muitos continuam trabalhando e acumulando renda do trabalho e aposentadoria no curto prazo, mesmo que a custa de uma renda menor no futuro, quando efetivamente perdem a capacidade laboral.

\section{GRÁFICO 5}

Idade média de aposentadoria por tempo de contribuição no RGPS

Brasil - 1993 a 2013

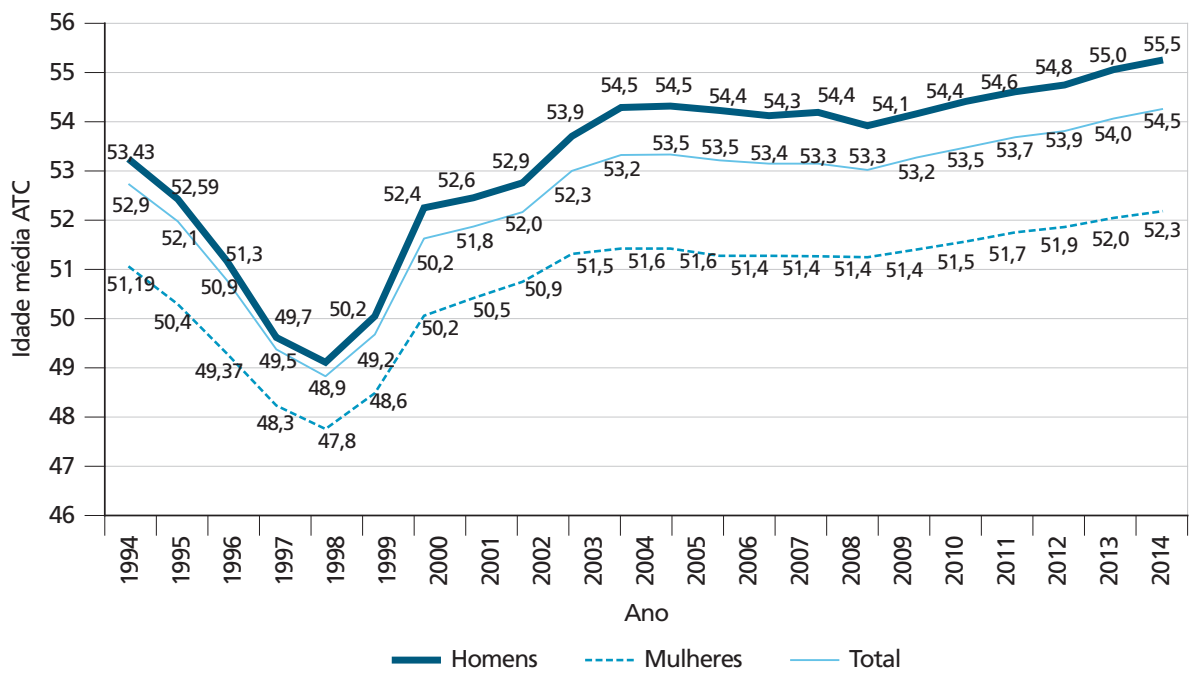

Fonte: Ministério do Trabalho e Previdência Social.

Elaboração dos autores.

Essa opção é ainda reforçada pela expectativa de que pode ser possível aumentar o valor da aposentadoria no futuro por meio da desaposentação, que náo é concedida de forma administrativa, mas cuja possibilidade está sendo analisada pelo Supremo Tribunal Federal (STF). Nesse sentido, a desaposentação, sem devolução dos valores recebidos, caso venha a ser aprovada pelo STF, reforçaria ainda mais o problema das aposentadorias precoces, funcionando como um prêmio ou um 
grande incentivo para se aposentar de forma precoce, razão pela qual é totalmente incoerente com a sustentabilidade da previdência social.

Nesse ponto, cabe destacar que o objetivo do fator era buscar equilíbrio entre contribuiçóes e o fluxo esperado de pagamento de aposentadoria. Esse equilíbrio poderia ser obtido pela postergação da aposentadoria ou pela reduçáo do valor do benefício em caso de não postergação ou por uma combinação dessas duas possibilidades. Como ainda prevaleceram idades médias bastantes precoces, o resultado foi uma reduçáo relevante no valor médio das ATCs no período de 2000 a 2014, embora tenha continuado a ser a espécie com maior valor médio.

TABELA 14

Concessão das aposentadorias por tempo de contribuição em 2014 por faixa etária do segurado no momento da aposentadoria

(Em \% do total acumulado)

\begin{tabular}{lccc}
\hline Faixa de idade & Homem & Mulher & Total \\
\hline Até 49 anos & 5,2 & 24,2 & $\mathbf{1 1 , 4}$ \\
50 a 54 anos & 39,0 & 67,9 & $\mathbf{4 8 , 4}$ \\
55 a 59 anos & 76,9 & 95,6 & $\mathbf{8 3 , 0}$ \\
60 a 64 anos & 98,6 & 99,6 & $\mathbf{9 8 , 9}$ \\
65 anos ou mais & 100,0 & 100,0 & $\mathbf{1 0 0 , 0}$ \\
\hline
\end{tabular}

Fonte: Ministério do Trabalho e Previdência Social.

Elaboração dos autores.

Cabe enfatizar, também, em relação aos descontos, que reduzir a aposentadoria para aqueles que se aposentam mais cedo é um procedimento bastante comum entre os países, ou seja, muitos têm regras de desconto ou de redução no valor do benefício caso seja feita a opção por uma aposentadoria antecipada. As regras de desconto variam muito de país para país, mas a aplicação dele é extremamente normal, que é exatamente o papel do fator, que possui a vantagem de permitir um ajuste automático à demografia, embora seja uma fórmula de difícil entendimento para a sociedade de um modo geral. Além disso, a maioria dos países tem uma idade mínima e a possibilidade de antecipação é bastante limitada, de poucos anos em geral, de tal sorte que é pouco comum ver pessoas aposentando na faixa dos 50 anos, como ocorre no Brasil com a ATC.

De qualquer forma, esses elevados níveis de desconto também deixam claro o forte impacto que a aplicação da regra 85/95 terá no valor dos benefícios e, por conseguinte, no aumento da despesa do RGPS. A título de exemplo, como pode ser visto na tabela 7 , no caso de uma mulher com 52 anos de idade e 30 anos de contribuição, a postergação de apenas um ano e meio, para atingir a soma de 85 , permite um incremento no valor do benefício de cerca de $59 \%$. Claramente, é uma relação extremamente desequilibrada entre tempo adicional de 
trabalho, que talvez ocorreria mesmo com a aposentadoria, e o incremento no valor do benefício. Como colocado, uma mulher com 52 anos tem uma expectativa de sobrevida de 30,2 anos, de tal sorte que poderia se esperar uma redução na duração do benefício, mesmo sem considerar a possibilidade dessa aposentadoria gerar uma pensão por morte, de apenas $5 \%$. O fluxo esperado de pagamento de benefícios, trazido a valor presente, a uma taxa de juros de $3 \%$ a.a., seria cerca de $47,3 \%$ maior com a regra 85 para essa mulher típica.

No caso de um homem, com 55 anos de idade e 35 anos de contribuição, a postergação da aposentadoria de dois anos e meio, para atingir a soma de 95 , traria um incremento no valor da aposentadoria de cerca de 42,8\%. Um homem com 55 anos de idade, tem uma expectativa de sobrevida de 23,6 anos, de tal sorte que a postergação reduziria a duração esperada próxima de $10 \%$. O aumento do valor esperado do fluxo de pagamento de benefícios trazido a valor presente, com uma taxa de juros de $3 \%$ a.a., é de $22,6 \%$. Todos esses dados deixam claro que haverá um aumento expressivo da despesa por conta da alteração nas regras de aplicação do fator previdenciário. A progressividade proposta pela MP no 676, e sancionada pela Lei ํㅡㄴ $13.183 / 2015$, apenas diminui o incremento da despesa, que ainda permanece expressivo, até pelo fato de a progressão ter ficado ainda mais lenta no Congresso, de tal sorte que o fator 90/100 será atingido apenas, na prática, no começo de 2027 e, em princípio, parar depois de 2027.

A parada da progressão é completamente inadequada do ponto de vista fiscal, pois com o contínuo incremento da expectativa de sobrevida esperada, também se espera que o fator previdenciário reduza ainda mais no futuro para uma mesma combinação de idade e tempo de contribuição, que implica aumentos de despesas crescentes no futuro com o fator 85/95 e também com o fator 90/100.

QUADRO 4

Impacto da aplicação da regra 85/95 sobre o valor dos benefícios da aposentadoria por tempo de contribuição

\begin{tabular}{|c|c|c|}
\hline \multicolumn{2}{|c|}{ Mulher } \\
\hline $\begin{array}{l}\text { Fator com } 52 \text { anos de idade e } 30 \text { anos } \\
\text { de contribuição (soma de 82) }\end{array}$ & $\begin{array}{l}\text { Fator com postergação da aposentadoria } \\
\text { de um ano e meio para atingir 85 }\end{array}$ & $\begin{array}{l}\text { Aumento no valor do benefício com } \\
\text { regra 85 em \% (considerando apenas } \\
\text { alteração no fator) }\end{array}$ \\
\hline 0,629 & 1,00 & $+59 \%$ \\
\hline $\begin{array}{l}\text { Fator com } 55 \text { anos de idade e } 35 \text { anos } \\
\text { de contribuição (soma de } 90)\end{array}$ & $\begin{array}{l}\text { Fator com postergação da aposentadoria } \\
\text { de dois anos e meio para atingir 95 }\end{array}$ & $\begin{array}{l}\text { Aumento no valor do benefício com } \\
\text { regra 95 em \% (considerando apenas } \\
\text { alteração no fator) }\end{array}$ \\
\hline 0,700 & 1,00 & $+42,8 \%$ \\
\hline
\end{tabular}

Elaboração dos autores, com base em dados do Ministério do Trabalho e Previdência Social. 
Há outros riscos associados à MP no 676 . A defesa que a medida poderia gerar alguma economia a curto prazo, pela postergaçáo, tendo em vista os elevados ganhos associados, tem alguns riscos que precisam ser apontados. Em primeiro lugar, a alteração cria alguma possibilidade de criação de passivo, se não pela via judicial, pela pressão do Legislativo, bem como também pode ter efeitos negativos sobre a votação da desaposentação. Certamente, muitos daqueles que sofreram efeito do fator no período de 2000 até junho de 2015 tendem a querer aproveitar-se da regra 85/95 e devem entrar com açóes na justiça pedindo essa "equiparaçáo". Mesmo que prevaleça, como já ocorreu no caso das pensōes, o diagnóstico na justiça de que vale a legislação previdenciária no momento do requerimento e, portanto, que não caberia retroagir com essa regra, certamente haverá muitas iniciativas no Poder Legislativo que buscarão que a referida regra seja aplicada de forma retroativa. Esse é um resultado natural e será, provavelmente, inevitável o surgimento de uma forte pressão política para retroagir o 85/95, fato que deverá criar, no futuro, ainda mais incerteza sobre a questão fiscal.

A possibilidade que o 85/95 seja aplicado de forma retroativa, seja via judicial, seja por pressão do Legislativo, implica a geração de um passivou ou esqueleto bilionário. Como pode ser visto pelo gráfico 6 , o fator previdenciário gerou uma redução das despesas de cerca de $\mathrm{R} \$ 75$ bilhóes no período de 2000 a 2014, com preços de janeiro de 2015 , sendo R \$ 14,1 bilhóes apenas no ano de 2014. Nota-se, como esperado, que a reduçấo das despesas tende a crescer de forma expressiva ao longo do tempo, tendo em vista que aumenta o estoque de benefícios afetados pelo fator.

\section{GRÁFICO 6}

Redução da despesa devido ao fator previdenciário - Brasil, 1993 a 2014

(Em R\$ bilhões, a preços de janeiro de 2015)

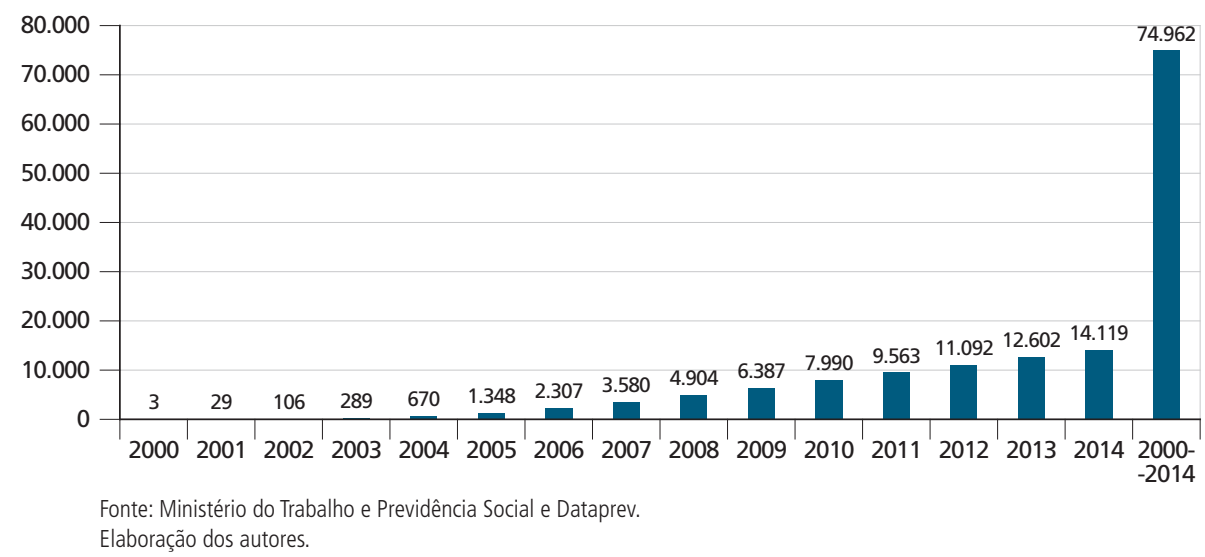

Um ponto que chama atenção é que a redução da despesa com fator previdenciário, crescente ao longo do tempo, foi comprometida pela regra 85/95 progressiva 
para 90/100. De modo, ao mesmo tempo, similar e inverso, também se espera que o efeito dessas alteraçóes na despesa do RGPS ocorra de forma crescente ao longo do tempo, à medida que aumenta o estoque de benefícios afetados por essa nova regra, que altera toda trajetória de valor do benefício por longos períodos de tempo.

Além do risco de passivo e adoção da regra de forma retroativa, um percentual relevante das aposentadorias concedidas em 2014 cumpria a condicionalidade de uma soma de 85 ou 95 e tinham fator menor que um. Para essas aposentadorias, haveria incremento no valor do benefício sem qualquer postergação, de forma imediata. De forma mais concreta, em 2014, 25,2\% das aposentadorias por tempo de contribuição concedidas para homens tinham soma de idade mais tempo de contribuição igual ou maior que 95 , sendo a maior parte com fator menor que um. Para as mulheres, 37,2\% das ATCs concedidas em 2014 tinham soma de idade mais tempo de contribuiçáo igual ou maior que 85 e, portanto, também teriam incremento no valor da aposentadoria sem qualquer postergação. Mais que isso, existe a possibilidade que parte dos segurados postergassem em algum grau sua aposentadoria para tentar ter um valor do fator previdenciário mais próximo de um ou mesmo igual ou maior que um. Com a adoção da regra 85/95 progressiva, a postergação necessária para chegar no fator igual a um diminui de forma significativa em relação ao que ocorreria sem a referida regra e, portanto, haverá casos em que pode haver antecipação e não postergação.

De qualquer forma, a defesa da mudança por algum efeito de postergação é esdruxula, porque no médio e longo prazo a medida gerará aumento expressivo da despesa com caráter regressivo, e as políticas previdenciárias deveriam ser pautadas por horizontes longos e não apenas por alguns poucos anos. Uma razão óbvia para essa preocupação é que essa mudança na regra de concessão terá efeito por várias décadas e comprometerá por longo período de tempo as contas do RGPS. A duração atual das ATCs está próxima de vinte anos, sendo que, como mostrado anteriormente, no caso das mulheres, a expectativa de sobrevida na idade média de ATC atual chega a trinta anos, que com a possibilidade de pensão por morte, pode-se estar falando de um aumento na despesa pelas quatro próximas décadas.

Outra fragilidade da proposta da $\mathrm{MP}$ no 676 , diz respeito à progressão apresentada. Embora não exista nenhuma justificativa oficial mais detalhada a respeito do critério utilizado para estabelecer de forma objetiva a progressão, além da consideração genérica de incremento da expectativa de sobrevida, o fim da progressão em 90/100 para 2027 é pouco adequado do ponto de vista fiscal, tendo em vista que se espera a continuidade do incremento da expectativa de sobrevida, mesmo muito tempo depois de 2027. Se por um lado, tal estratégia evita resistências políticas de tentar estabelecer alguma regra de progressão para um ano tão distante 
como 2027, por outro lado, acaba por dificultar a necessária disseminação de que questóes previdenciárias precisam ser tratadas como de longo prazo.

Poderia até se argumentar que 90/100 seria o patamar a partir do qual os segurados estariam próximos dos parâmetros da aposentadoria por idade, a partir da soma de idade de 65 anos para homens e 35 anos de contribuição e, respectivamente, 60 e 30 para mulheres, mas essa possível linha de argumentação tem equívocos. Em primeiro lugar, dado o perfil laboral dos que se aposentam por tempo de contribuição, os segurados tendem a conseguir atingir o parâmetro de 35/30 anos de contribuição antes da idade de 65/60 anos, tanto que a média atual é de 55/52 anos de idade. Nesse sentido, muitos segurados devem atingir o fator 90/100 antes de chegarem às idades limites de 65/60 anos.

Ademais, como colocado anteriormente, não há base atuarial para a regra 85/95, quer fixa ou progressiva, a não ser o desejo político de pagar aposentadorias de maior valor para aqueles que já têm os benefícios com a maior média no âmbito do RGPS. Nesse sentido, do ponto de vista da sustentabilidade fiscal e como forma de evitar um incremento elevado nas despesas, de forma paliativa frente a uma possível incapacidade política de evitar alteraçôes no fator previdenciário, poder-se-ia buscar pelo menos uma progressão que aproximasse o ponto de corte do fator próximo de um. Contudo, tanto o ponto de partida inicial (85/95) resulta em fatores muito distantes de um (0,7 para homens e 0,6 para mulheres), como a progressão até $90 / 100$ até 2027 são contraproducentes, até porque o fator tende a se tornar mais duro ao longo do tempo com o incremento da expectativa de sobrevida.

Atualmente, o fator associado a uma soma de noventa para mulheres, poderia ser o de idade de 56 anos e 34 anos de contribuição, que resultaria em um fator de 0,816 , ou seja, o ganho previsto para mulheres, usando a tabela atual do fator, implica aumento no valor do benefício da ordem de 22,5\%. Contudo, em 2027, a estimativa é a de que o fator seja ainda menor, em função do aumento na expectativa de sobrevida. A título de exemplo, em 2000 e 2008, o fator associado a uma mulher de 56 anos de idade e 34 anos de contribuição eram de, respectivamente, 0,990 e 0,850 .

No caso dos homens, o fator associado a uma soma de 100 poderia ser o de idade de 60 anos e 40 anos de contribuição, que resultaria em um fator de 0,981. Contudo, em 2027, a estimativa é a de que o fator seja menor, em função do aumento na expectativa de sobrevida. A título de exemplo, em 2000 e 2008, o fator associado a um homem de 60 anos de idade e 40 anos de contribuição eram de, respectivamente, 1,216 e 1,023.

Um aspecto já ressaltado é que esse aumento da despesa terá caráter regressivo. $\mathrm{O}$ valor médio das aposentadorias por tempo de contribuição concedidas em 
2013 foi de $\mathrm{R} \$ 1.582,74$, tendo sido concedidas cerca de 291 mil aposentadorias. Há dificuldade na Pnad/IBGE de identificar, de forma precisa, aqueles que são beneficiários de aposentadoria por tempo de contribuição do RGPS. Embora todos os homens e mulheres aposentados, respectivamente, com menos de 60 e 55 anos de idade sejam potenciais beneficiários desse tipo de benefício, podem também ser aposentados por invalidez, aposentados especiais, professores ou mesmo servidores públicos aposentados. Por essa razão, há uma grande dificuldade em uma identificação precisa dos beneficiários, além do que essa seleção limitar-se-ia, ainda, às concessões recentes que, em princípio, são o público beneficiário, caso se desconsidere a possibilidade de passivo. De qualquer forma, é possível fazer algumas avaliaçóes, ainda que com limitaçóes.

De forma a tentar selecionar os beneficiários por aposentadoria por tempo de contribuição, com base nos microdados da Pnad/IBGE de 2013, foram filtrados homens beneficiários de aposentadoria com idade abaixo de 60 anos e mulheres com menos de 55 anos, para excluir benefícios por idade. Com base nessa extração, seria possível identificar concessões recentes de aposentadoria por tempo de contribuição, embora, também, teoricamente, acabe captando casos de especial e por invalidez, bem como aposentados dos regimes próprios. Mesmo com essas limitaçóes, foi possível identificar cerca de 2,8 milhôes de aposentados, sendo que desse total, utilizando a renda de todas as fontes ${ }^{15}$, cerca de 1,1 milhão (39\% do total) estariam entre os $50 \%$ de menor rendimento e 1,7 milhão (61\% do total) estariam entre os $50 \%$ de maior rendimento. Uma forma de tentar aprimorar esse exercício é aplicar mais filtros, mais especificamente, do total de 2,8 milhóes de aposentados, selecionar aqueles que estavam ocupados, como uma forma de tentar excluir, teoricamente, os aposentados por invalidez, embora possam excluir também os beneficiários da ATC. De qualquer forma, é provável que os beneficiários de novas concessóes de ATC, dada a idade precoce, tendam a ter uma probabilidade bem razoável de se manterem no mercado de trabalho, acumulando renda do trabalho e aposentadoria, que explicaria aceitar descontos tấo elevados decorrentes do fator previdenciário. Essa acumulaçáo de trabalho e aposentadoria, por sinal, agrava ainda mais o caráter regressivo da alteração no fator. Com esse critério, foram identificados 874 mil aposentados, sendo que desse total $94 \mathrm{mil}(10,8 \%$ do total) estavam entre os $50 \%$ com menor rendimento e cerca 780 mil $(89,2 \%$ do total) estavam entre os $50 \%$ de maior rendimento.

As análises anteriores foram feitas considerando a renda individual de todas as fontes de rendimento, mas também é importante analisar o impacto distributivo por meio do rendimento domiciliar per capita. Considerando essa variável, do total de 2,8 milhóes de aposentados com idade menor que 60 anos para homens e que

15. Foi utilizada a variável V4720, excluindo os casos de renda igual a zero e daqueles sem declaração. 
55 para mulheres, cerca de 2,2 milhóes estavam com nível de renda domiciliar per capita acima da mediana e, portanto, cerca de $76,5 \%$ estavam entre os $50 \%$ mais ricos. Considerando, desse total de 2,8 milhóes de aposentados, apenas aqueles que estavam ocupados, chega-se a um resultado ainda mais regressivo: $88,5 \%$ estavam entre os $50 \%$ mais ricos.

Portanto, esses dados deixam claro que a alteração do fator previdenciário com a adoção da regra 85/95 progressiva para 90/100 terá efeitos negativos sobre a sustentabilidade do RGPS, que já será afetada pelo envelhecimento populacional, na medida em que gera aumentos expressivos no valor dos benefícios e, consequentemente, da despesa. Ademais, esse aumento da despesa tem caráter regressivo, na medida em que os beneficiários da ATC são aqueles com maior valor médio de benefício e, em geral, é vinculado aos trabalhadores com maior estabilidade no mercado formal de trabalho e maior nível de renda. Os trabalhadores com trajetória laboral mais precária, maior tempo na informalidade e/ou no desemprego e menor nível de renda tendem a ter probabilidade muito maior de serem aposentados por idade do que por tempo de contribuição. $\mathrm{Na}$ realidade, há uma situaçáo em que os trabalhadores urbanos com menor estabilidade no mercado laboral e menor nível de renda, que possuem dificuldade de conseguir 35/30 anos de contribuição, tendem a se aposentar por idade enfrentando uma idade mínima de 65/60 anos. Por sua vez, os trabalhadores com mais estabilidade e maiores níveis de renda, que conseguem se aposentar por tempo de contribuição, não têm idade mínima. A regra 85/95 progressiva será regressiva, pois aumentará de forma desproporcional o valor dos benefícios de aposentadorias precoces.

O ideal seria uma reforma estrutural que levasse a um equilíbrio com benefícios de valor maior decorrente de idades mais elevadas de aposentadoria, mas com equilíbrio entre o aumento da idade e o incremento no valor do benefício.

\section{REFERÊNCIAS}

ANSILIERO, G.; COSTANZI, R. N.; PEREIRA, E. A pensão por morte no âmbito do regime geral de previdência social. Revista Planejamento e Políticas Públicas, n. 42, jan./jun. 2014.

COSTANZI, R. Regras para Pensão por Morte. Informaçóes FIPE, n. 414, p. 9-12, ISSN 1678-6335, mar. 2015.

COSTANZI, R. N.; ANSILIERO, G. Repensando a pensão por morte no Brasil: evidências nacionais e notas comparativas com a América Latina. Revista ResPublica, n. 2, v.14, jul./dez. 2015. 
MATIJASCIC, M.; KAY, S. 2014. Brazilian pension model: the pending agenda. International Social Security Review, Blackwell, London, v. 67 n. 1, p. 71-93, 2014. MATIJASCIC, M.; KAY, S. J. Pensions in Brazil: reaching the limits of parametric reform in Latin America. In: KAY, S. J.; SINHA, T. (Eds.). Lessons from pension reform in the Americas. Oxford, Oxford University Press, 2008.

ROCHA, R. R.; CAETANO, M. A.-R. O Sistema previdenciário brasileiro: uma avaliação de desempenho comparada. Brasília: Ipea, 2008. (Texto para Discussão, n. 1.331). 